\title{
Supercritical Fluid Geochemistry in Geothermal Systems
}

\author{
Matylda Heřmanská (D), Barbara I. Kleine, and Andri Stefánsson
}

Institute of Earth Sciences, University of Iceland, Sturlugata 7, Reykjavík 101, Iceland

Correspondence should be addressed to Matylda Heřmanská; mattylda@hi.is

Received 2 May 2019; Accepted 1 July 2019; Published 5 August 2019

Academic Editor: John A. Mavrogenes

\begin{abstract}
Copyright ( 2019 Matylda Heřmanská et al. This is an open access article distributed under the Creative Commons Attribution License, which permits unrestricted use, distribution, and reproduction in any medium, provided the original work is properly cited.
\end{abstract}

\begin{abstract}
Supercritical fluids exist in the roots of many active high-temperature geothermal systems. Utilization of such supercritical resources may multiply energy production from geothermal systems; yet, their occurrence, formation mechanism, and chemical properties are poorly constrained. Flow-through experiments at $260^{\circ} \mathrm{C}$ and $400-420^{\circ} \mathrm{C}$ were performed to study the chemical and mineralogical changes associated with supercritical fluid formation near shallow magmatic intrusions by conductive heating and boiling of conventional subcritical geothermal fluids. Supercritical fluids formed by isobaric heating of liquid geothermal water had similar volatile element concentrations (B, C, and S) as the subcritical water. In contrast, mineral-forming element concentrations ( $\mathrm{Si}, \mathrm{Na}, \mathrm{K}, \mathrm{Ca}, \mathrm{Mg}$, and $\mathrm{Cl}$ ) in the supercritical fluid were much lower. The results are consistent with the observed mineral deposition of quartz, aluminum silicates, and minor amount of salts during boiling. Similar concentration patterns have been predicted from geochemical modeling and were observed at Krafla, Iceland, for the IDDP-1 supercritical fluid discharge. The experimental results confirm previous findings that supercritical fluids may originate from conductive heating of subcritical geothermal reservoir fluids characterized by similar or lower elemental concentrations with minor input of volcanic gas.
\end{abstract}

\section{Introduction}

Volcanic geothermal systems are associated with magmatic intrusions in the upper part of the Earth's crust characterized by increased temperature, specific fluid enthalpy, and convection of groundwater [1]. Conventional exploitation of geothermal fluids from such systems typically produces an average of $\sim 3-5 \mathrm{MW}$ electric power per well [2] with a world total exploitation of geothermal energy in 2018 corresponding to $\sim 14.4 \mathrm{GW}$ [3]. Conductive heat transfer from a magmatic intrusion to the surrounding groundwater occurs in the roots of the geothermal system below the depth of typical conventional geothermal wells. Recent modeling suggests that supercritical fluids with temperatures and enthalpies exceeding $\sim 400^{\circ} \mathrm{C}$ and $\sim 3000 \mathrm{~kJ} \mathrm{~kg}^{-1}$, respectively, exist at the boundary between geothermal systems and the magmatic heat source, with such fluids possibly capable of generating up to 30-50 MW of electricity from a single well or ten times more than conventional geothermal wells [4].
Supercritical geothermal fluids have commonly been classified based on the critical temperature $\left(T_{c}=373.976^{\circ} \mathrm{C}\right)$ and pressure $\left(P_{c}=22.01 \mathrm{MPa}\right)$ of pure water $\left(\mathrm{H}_{2} \mathrm{O}\right)$ [5]. Such a definition can lead to an artificial boundary in the phase diagram of water, across which there is actually a continuous change in fluid properties. Moreover, for binary salt-water fluids, the term "supercritical" may not fully describe the fluid phase properties, as critical behavior occurs along critical temperature and pressure, implying fluid phase separation rather than homogenization. Here and following Liebscher and Heinrich [6], the term supercritical is defined as a single-phase vapor with a temperature above the critical temperature. Supercritical fluids have been suggested to form by groundwater circulation near the intrusion $[1,7,8]$ with or without input from magmatic gas [9-11]. More than 25 deep wells sunk into the geothermal fields at The Geysers, Salton Sea, and Hawaii (USA); Kakkonda (Japan); Larderello (Italy); Krafla, Nesjavellir, and Reykjanes (Iceland); Los Humeros (Mexico); and Menengai (Kenya) have reached 


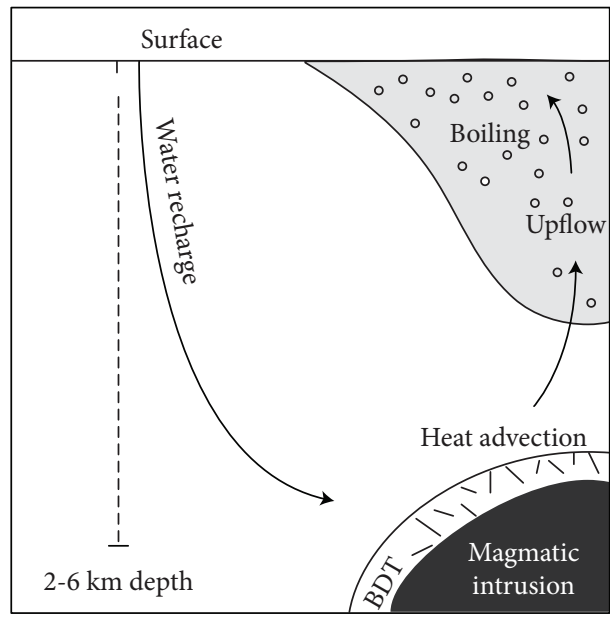

(a)

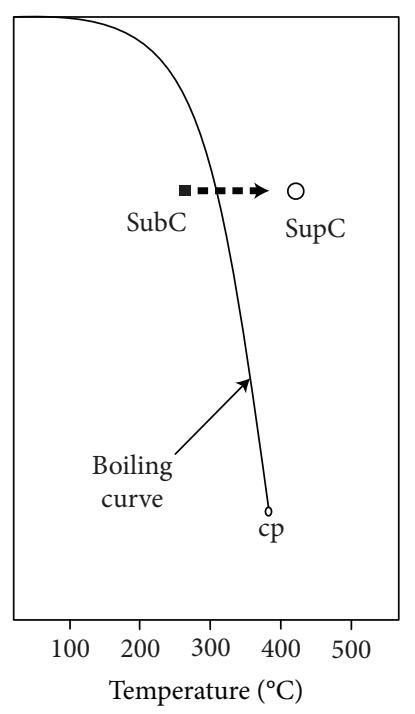

(b)

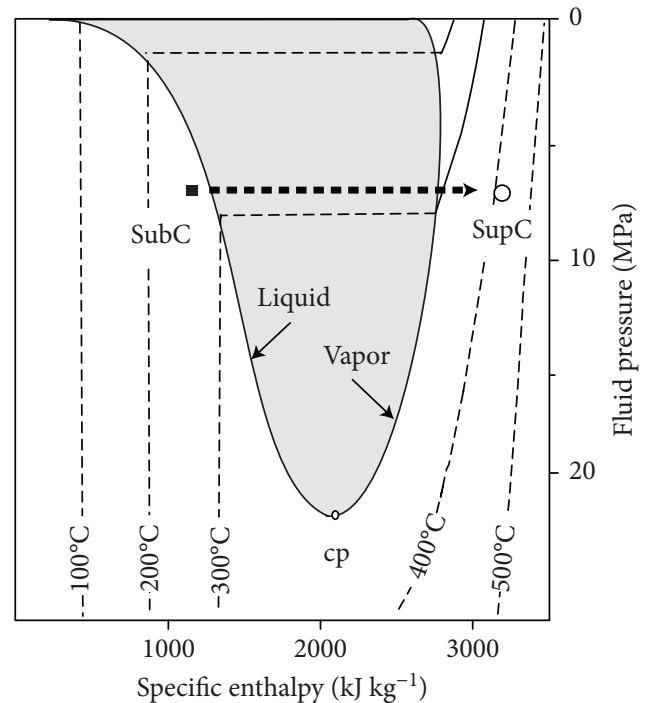

(c)

FIgURE 1: Main characteristics of a volcanic geothermal system. (a) Conceptual model showing fluid flow paths, the brittle-ductile transition (BDT) between the magmatic heat source and the circulating geothermal fluid, and depressurization boiling near the surface. Constructed based on Arnórsson et al. [60] and Scott et al. [8]. (b) The boiling curve of water. (c) The phase diagram of water showing pressure, specific enthalpy, and temperature relations. Also shown are the subcritical (SubC) to supercritical (SupC) conditions of the experiments carried out in this study.

temperatures in excess of the critical temperature of water and, in some cases, have even encountered magma [12]. The most extensive project aiming at obtaining supercritical fluids for geothermal utilization is the Iceland Deep Drilling Project (http://www.iddp.is). In 2009, the IDDP1 well at Krafla (NE Iceland) came to a halt after drilling into molten magma at $\sim 2.1 \mathrm{~km}$ depth [13]. After an initial heating period, the well discharged supercritical fluids with temperatures of $\sim 440^{\circ} \mathrm{C}$ and eventually reached a maximum temperature of $459^{\circ} \mathrm{C}$ and specific enthalpy of $\sim 3200 \mathrm{~kJ} \mathrm{~kg}^{-1}$ $[14,15]$. From March 2010 until September 2011, series of flow tests were conducted; however, due to the corrosive nature of the fluids, silica scaling, and thermal damage to the well casings, utilization proved to be challenging and the fluid discharge was eventually terminated [16]. In 2017, the second IDDP-2 well at Reykjanes (SW Iceland) reached its target depth of $4.6 \mathrm{~km}$ with a measured bottom hole temperature of $426^{\circ} \mathrm{C}$ [17]. At present, fluid discharges from IDDP-2 at surface are not characterized by supercritical temperatures. Thus, deep reservoir fluid composition has been estimated from fluid inclusion analysis of felsic veins consisting of a vapor phase dominated by water $(97.5 \mathrm{~mol} \%$ $\mathrm{H}_{2} \mathrm{O}, \sim 1.5 \mathrm{~mol} \% \mathrm{CO}_{2}, 0.7 \mathrm{~mol} \% \mathrm{H}_{2} \mathrm{~S}$, and traces of $\mathrm{H}_{2}$ ), Clrich brine ( $\mathrm{Fe}-\mathrm{K}$ chlorides, sylvite-halide solid solutions), and sulfides [18].

Magmatic intrusions emplaced into the upper parts of the Earth's crust may exsolve magmatic fluids at near lithostatic pressure, resulting in fracturing of the surrounding rocks and magmatic fluid migration $[19,20]$. Near magmatic intrusions, conductive heat addition to the surrounding groundwater system may also potentially form hightemperature supercritical fluids [1,7]. However, permeability may rapidly decrease at the brittle-ductile transition (BDT), possibly limiting the formation of such supercritical fluids to lithologies with basaltic glass transition temperatures above $\sim 400-450^{\circ} \mathrm{C}[1,7,21-23]$. While the relations between rock permeability and brittle-ductile behavior, as well as reservoir simulations around magmatic intrusions, have received considerable interest, less attention has been drawn to the geochemical properties of such supercritical fluids. Fluids originating from degassing magma are rich in $\mathrm{CO}_{2}$, $\mathrm{SO}_{2}, \mathrm{HCl}$, and $\mathrm{HF}$ [24]. In contrast, supercritical fluids formed by boiling of subcritical geothermal water of meteoric or seawater origin are considered to display similar concentrations of many volatile elements $\left(\mathrm{CO}_{2}, \mathrm{H}_{2} \mathrm{~S}, \mathrm{H}_{2}\right.$, and $\mathrm{B}$ ) as the original water, much lower than corresponding magmatic-gas concentrations, but negligible nonvolatile element concentrations ( $\mathrm{Si}, \mathrm{Na}, \mathrm{K}, \mathrm{Ca}$, and $\mathrm{Mg}$ ) [25-31]. The formation of supercritical fluids may also produce a silica deposit around the magmatic intrusion [25, 31, 32] (Figure 1).

In this study, flow-through experiments at $260^{\circ} \mathrm{C}$ and $400-420^{\circ} \mathrm{C}$ were performed to study how conductive heating of subcritical water form geothermal fluids at supercritical temperatures and how this affects fluid chemistry and associated secondary mineral formation. The results of the experiments were further compared with the recent model simulations of the chemical nature of supercritical fluids near magmatic intrusions and with the observed composition of the supercritical fluid discharged by the IDDP-1 [31].

\section{Methods}

2.1. Experimental Set-Up. Flow-through experiments at $260^{\circ} \mathrm{C}$ and $400-420^{\circ} \mathrm{C}$ and $6.9 \mathrm{MPa}$ reproduce geothermal reservoir conditions at subcritical and supercritical 

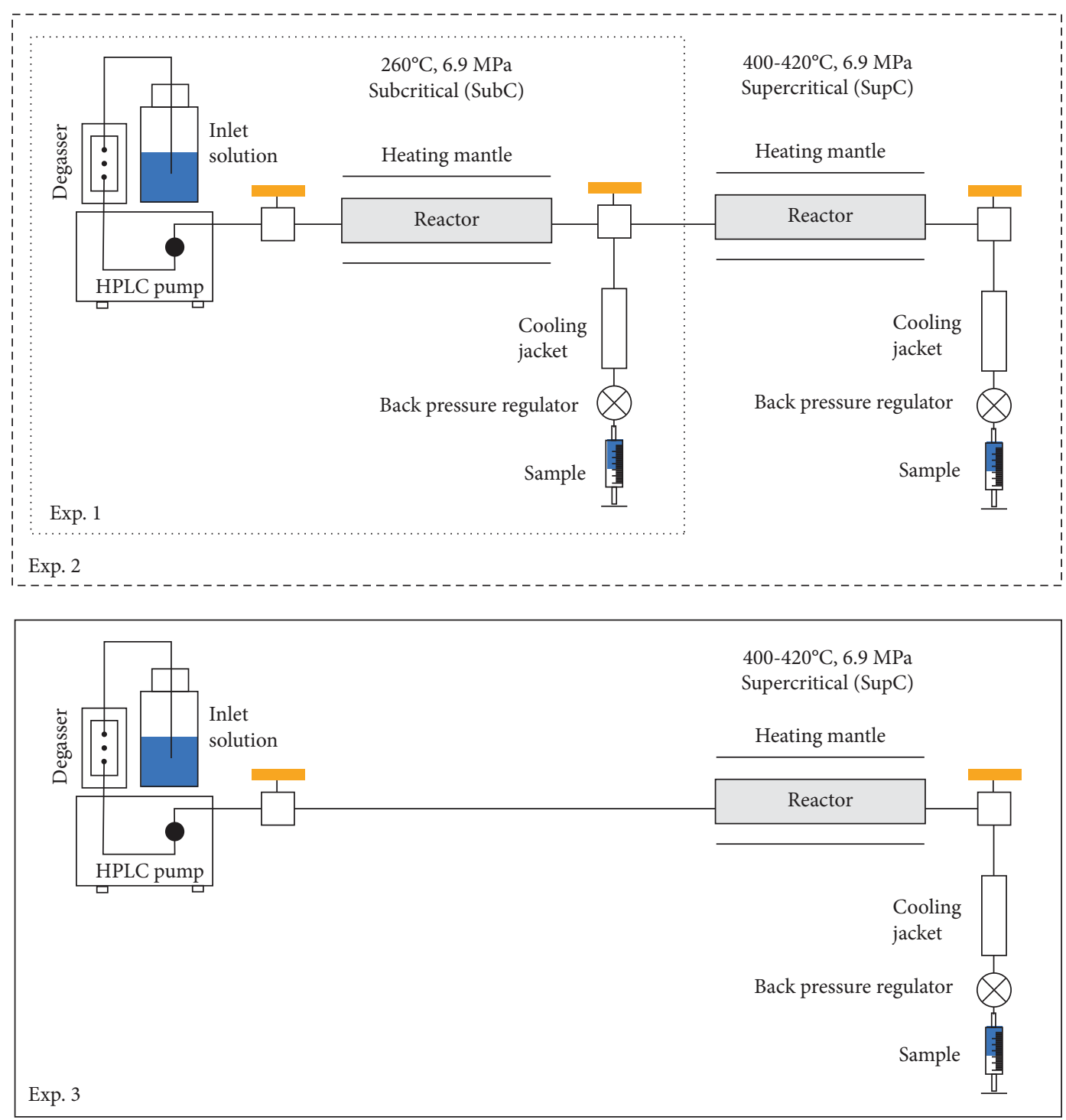

Figure 2: Schematic set-up of the experiments described in this study.

TABLE 1: Initial conditions of the experiments.

\begin{tabular}{lccccc}
\hline$\#$ & $t\left({ }^{\circ} \mathrm{C}\right)$ & $P(\mathrm{MPa})$ & $Q\left(\mathrm{~g} \mathrm{~min}^{-1}\right)$ & Material & $\begin{array}{c}\text { Grain size } \\
(\mu \mathrm{m})\end{array}$ \\
\hline SubC-1 & 260 & 6.9 & $0.09-0.26$ & BAS & $45-125$ \\
SupC-1 & 420 & 6.9 & $0.19-0.21$ & SS316-rod & \\
SupC-2 & 400 & 6.9 & $0.10-0.19$ & SS316-rod & \\
\hline
\end{tabular}

temperatures, respectively. A schematic illustration of the experimental set-up is shown in Figure 2, and a summary of experimental conditions is given in Table 1. All wetted parts of the experimental apparatus were made of inert material, including PEEK, titanium, and Inconel. Inlet solutions were pumped at a flow rate of $\sim 0.20 \mathrm{ml} / \mathrm{min}$ using an HPLC pump (Chromatech ${ }^{\circledR}$ ). The pressure was controlled at the end of the line by a back-pressure regulator (BPR, Biotech).

The first reactor (SubC), representing subcritical conditions, was heated to $260^{\circ} \mathrm{C}$ and filled with fine-grained
TABLE 2: Basaltic glass composition (BAS) ${ }^{\mathrm{a}}$.

\begin{tabular}{lcc}
\hline Element & & \\
\hline $\mathrm{SiO}_{2}$ & wt.\% & 48.12 \\
$\mathrm{Al}_{2} \mathrm{O}_{3}$ & wt.\% & 14.62 \\
$\mathrm{FeO}$ & wt.\% & 9.82 \\
$\mathrm{Fe}_{2} \mathrm{O}_{3}$ & wt.\% & 1.11 \\
$\mathrm{MgO}$ & wt.\% & 9.08 \\
$\mathrm{CaO}$ & wt.\% & 11.82 \\
$\mathrm{Na}_{2} \mathrm{O}$ & wt.\% & 1.97 \\
$\mathrm{~K}_{2} \mathrm{O}$ & wt.\% & 0.29 \\
$\mathrm{Cl}^{\mathrm{b}}$ & ppm & 220 \\
$\mathrm{CO}_{2}{ }^{\mathrm{b}}$ & ppm & 100 \\
$\mathrm{~B}^{\mathrm{b}}$ & ppm & 1.0 \\
\hline
\end{tabular}

${ }^{\mathrm{a}}$ Basaltic glass from Stapafell [62]. ${ }^{\mathrm{b}}$ Taken as for average basalts in Iceland, after Kaasalainen and Stefánsson [64]. 
TABLE 3: Chemical composition of the solutions from the SubC and SupC reactors. Concentrations are in ppm.

\begin{tabular}{|c|c|c|c|c|c|c|c|c|c|c|c|c|c|c|c|c|}
\hline Run \# & $t\left({ }^{\circ} \mathrm{C}\right)$ & $\mathrm{pH}$ & 1 & ${ }^{\circ} \mathrm{C}$ & $\mathrm{SiO}_{2}$ & B & $\mathrm{Na}$ & $\mathrm{K}$ & $\mathrm{Ca}$ & $\mathrm{Mg}$ & $\mathrm{Fe}$ & $\mathrm{Al}$ & $\mathrm{Cl}$ & $\mathrm{CO}_{2}$ & $\mathrm{SO}_{4}$ & $\mathrm{H}_{2} \mathrm{~S}$ \\
\hline \multicolumn{17}{|l|}{ Subcritical } \\
\hline SubC-1-S1 & 260 & 8.08 & I & 21 & 535 & 3.46 & 165 & 21.1 & 0.70 & 0.023 & 0.029 & 6.88 & 45.4 & 82.3 & 98.0 & 44.0 \\
\hline SubC-1-S2 & 260 & 8.02 & I & 21 & 526 & 3.36 & 160 & 30.8 & 1.00 & 0.010 & 0.060 & 6.21 & 43.2 & 87.1 & 180 & 38.5 \\
\hline SubC-1-S3 & 260 & 8.21 & I & 21 & 548 & 3.44 & 165 & 22.5 & 0.69 & 0.003 & 0.023 & 6.69 & 43.6 & 83.2 & 138 & 57.9 \\
\hline SubC-1-S4 & 260 & 8.50 & I & 21 & 493 & 3.46 & 168 & 23.0 & 1.72 & 0.004 & 0.154 & 5.13 & 44.7 & 99.0 & 142 & 40.9 \\
\hline SubC-1-S5 & 260 & 8.70 & I & 21 & 440 & 3.41 & 173 & 22.0 & 2.71 & 0.003 & 0.028 & 4.86 & 44.0 & 94.2 & 124 & 40.6 \\
\hline SubC-1-S6 & 260 & 9.03 & I & 21 & 383 & 3.38 & 177 & 21.9 & 3.04 & 0.002 & 0.019 & 5.61 & 43.2 & 73.9 & 164 & 40.6 \\
\hline SubC-1-S7 & 260 & 9.18 & I & 21 & 356 & 3.35 & 186 & 21.3 & 2.90 & 0.000 & 0.032 & 6.50 & 44.0 & 78.3 & 173 & 36.1 \\
\hline SubC-1-S8 & 260 & 9.37 & I & 21 & 336 & 3.38 & 196 & 20.7 & 2.45 & 0.005 & 0.020 & 6.48 & 46.1 & 76.6 & 137 & 49.1 \\
\hline SubC-1-S9 & 260 & 9.79 & I & 21 & 327 & 3.36 & 200 & 19.5 & 2.43 & 0.000 & 0.017 & 6.61 & 44.7 & 70.9 & 158 & 36.1 \\
\hline SubC-1-S10 & 260 & 9.63 & I & 21 & 332 & 3.38 & 205 & 19.3 & 2.22 & 0.002 & 0.046 & 6.48 & 45.4 & 63.8 & 188 & 36.1 \\
\hline SubC-1-S11 & 260 & 9.64 & l & 21 & 325 & 3.36 & 207 & 18.6 & 2.14 & 0.007 & 0.036 & 6.15 & 45.4 & 65.1 & 164 & 37.8 \\
\hline SubC-1-S12 & 260 & 9.60 & I & 21 & 329 & 3.36 & 212 & 55.5 & 2.21 & 0.005 & 0.058 & 5.96 & 50.0 & 66.0 & 202 & 26.9 \\
\hline SubC-1-S13 & 260 & 8.09 & I & 21 & 634 & 3.48 & 167 & 21.5 & 1.47 & 0.054 & 0.079 & 8.04 & 44.7 & 55.5 & 154 & 30.7 \\
\hline SubC-1-S14 & 260 & 8.00 & I & 21 & 674 & 3.46 & 161 & 21.9 & 1.58 & 0.012 & 0.042 & 5.26 & 44.0 & 90.7 & 152 & 27.3 \\
\hline SubC-1-S15 & 260 & 8.40 & I & 21 & 559 & 3.46 & 171 & 22.4 & 1.44 & 0.005 & 0.012 & 6.23 & 44.3 & 67.3 & 207 & 17.4 \\
\hline SubC-1 inlet ${ }^{\mathrm{a}}$ & 260 & 8.82 & l & 21 & 453 & 3.41 & 181 & 24.1 & 1.91 & 0.009 & 0.044 & 6.21 & 44.8 & 76.9 & 159 & 37.3 \\
\hline Krafla w $17^{\mathrm{b}}$ & $275^{\mathrm{d}}$ & 9.30 & I & 21 & 699 & 1.49 & 144 & 24.0 & 0.35 & 0.012 & 0.025 & 1.94 & 24.6 & 49.1 & 79.6 & 53.5 \\
\hline Krafla w $37^{\mathrm{c}}$ & $265^{\mathrm{e}}$ & 7.95 & I & 20 & 488 & 3.46 & 156 & 22.8 & 7.61 & 0.012 & 0.018 & 0.84 & 46.1 & 106 & 90.8 & 40.9 \\
\hline \multicolumn{17}{|l|}{ Supercritical } \\
\hline SupC-1-S17 & 420 & 5.06 & I & 21 & 5.3 & 3.19 & 0.2 & 0.07 & 0.06 & 0.002 & 0.050 & 0.022 & 0.35 & 8.32 & 0.45 & 13.9 \\
\hline SupC-1-S18 & 420 & 4.96 & I & 21 & 3.6 & 4.16 & 0.1 & 0.06 & 0.09 & 0.005 & 0.069 & 0.062 & & 19.8 & 0.49 & 17.2 \\
\hline SupC-1-S19 & 420 & 4.75 & l & 21 & 2.3 & 3.30 & 0.1 & 0.02 & 0.02 & 0.002 & 0.042 & 0.027 & 0.46 & 24.5 & 0.32 & 8.18 \\
\hline SupC-1-S20 & 420 & 4.90 & I & 21 & 2.1 & 3.35 & 0.1 & 0.02 & 0.02 & 0.002 & 0.026 & 0.018 & 0.37 & 15.7 & 0.27 & 10.5 \\
\hline SupC-1-S21 & 420 & 4.50 & I & 21 & 1.5 & 2.58 & 0.2 & 0.04 & 0.02 & 0.003 & 0.024 & 0.044 & 0.48 & 268 & 0.40 & 12.0 \\
\hline SupC-1-S22 & 420 & 5.00 & l & 21 & 1.4 & 3.47 & 0.2 & 0.05 & 0.05 & 0.003 & 0.029 & 0.029 & 0.46 & 25.1 & 0.38 & 7.56 \\
\hline SupC-1-S23 & 420 & 4.40 & I & 21 & 1.4 & 3.42 & 0.1 & $<0.1$ & 0.03 & 0.004 & 0.039 & 0.081 & & 225 & 0.35 & 28.0 \\
\hline SupC-1-S24 & 420 & 4.60 & I & 21 & 1.3 & 2.92 & 0.1 & 0.04 & 0.02 & 0.003 & 0.037 & 0.064 & 0.36 & 105 & 0.33 & 13.9 \\
\hline SupC-2-SSE1 & 400 & 3.99 & I & 22 & 4.6 & 1.30 & 0.5 & $<0.1$ & 0.12 & 0.029 & 0.208 & 0.173 & 1.89 & 46.5 & 0.26 & 13.8 \\
\hline SupC-2-SSE2 & 400 & 4.17 & I & 22 & 4.3 & 1.43 & 1.6 & 0.25 & 0.15 & 0.041 & 0.181 & 0.060 & 2.13 & 35.4 & 0.78 & 10.7 \\
\hline SupC-2-SSE3 & 400 & 3.97 & l & 22 & 3.1 & 1.47 & 1.1 & 0.26 & 0.08 & 0.019 & 0.099 & 0.075 & 1.90 & 38.0 & 0.67 & 40.0 \\
\hline SupC-2-SS34 & 400 & 3.68 & I & 22 & 2.9 & 1.32 & 1.5 & 0.19 & 0.06 & 0.021 & 0.083 & 0.059 & 2.85 & 59.6 & 0.54 & 29.9 \\
\hline SupC-2-SSE5 & 400 & 3.24 & I & 21 & 2.8 & 1.37 & 0.4 & $<0.1$ & 0.11 & 0.019 & 0.058 & 0.041 & 2.05 & 55.3 & 0.36 & 24.9 \\
\hline SupC-2-SSE6 & 400 & 3.65 & l & 21 & 1.2 & 1.38 & 1.0 & $<0.1$ & 0.17 & 0.028 & 0.102 & 0.071 & 1.41 & 53.7 & 1.74 & 25.1 \\
\hline SupC-2-SSE7 & 400 & 3.41 & l & 21 & 1.4 & 1.44 & 0.8 & $<0.1$ & 0.04 & 0.023 & 0.080 & 0.056 & 1.75 & 135 & 1.50 & 31.2 \\
\hline
\end{tabular}

${ }^{\mathrm{a}}$ The average inlet composition of subcritical experiments SubC-1-n that served as inlet solution for supercritical experiment SupC-1-n. ${ }^{\mathrm{b}} \mathrm{Krafla}$ w17 was used as an inlet for subcritical experiments SubC-1-n. Note: the inlet solution represents the liquid phase only discharge from the well w17. ${ }^{\mathrm{C}}$ The Krafla w37 was used as inlet for the supercritical experiments SupC-2-n. Note: the inlet solution represents the liquid phase only discharge from the well w37. ${ }^{\mathrm{d}}$ Based on Gudmundsson and Arnórsson [41]. ${ }^{\mathrm{e}}$ Based on Ntihabose [63].

basaltic glass (grain size fraction $<45 \mu \mathrm{m}$ ) from Stapafell, Iceland (Table 2). The second reactor (SupC), representing supercritical conditions, was heated to $400-420^{\circ} \mathrm{C}$. This reactor contained a stainless steel (316) threaded rod to capture deposits precipitating from the fluids. Three different experiments were carried out to test the effects of temperature and solution composition on fluid composition and alteration mineralogy. The initial solution in all cases was of natural geothermal water from Krafla, Iceland (Table 3 ). In experiment 1 , interaction between geothermal liquid water and basaltic rocks at subcritical temperatures $\left(260^{\circ} \mathrm{C}\right)$ was conducted. In experiments 2 and 3, the geothermal water either from the outlet subcritical reactor or directly from the inlet solution was pumped into a flowthrough reactor with a supercritical temperature of 400$420^{\circ} \mathrm{C}$. In all cases, the fluids were cooled down by an inline cooling jacket, followed by depressurization by a BPR and collection of fluid samples. At the end of each experiment, the solid deposits from the reactor were collected, dried at $50^{\circ} \mathrm{C}$, and mounted on a sample holder. Loose precipitates from the rod collected from the supercritical reactor were directly mounted on a sample holder to study the 

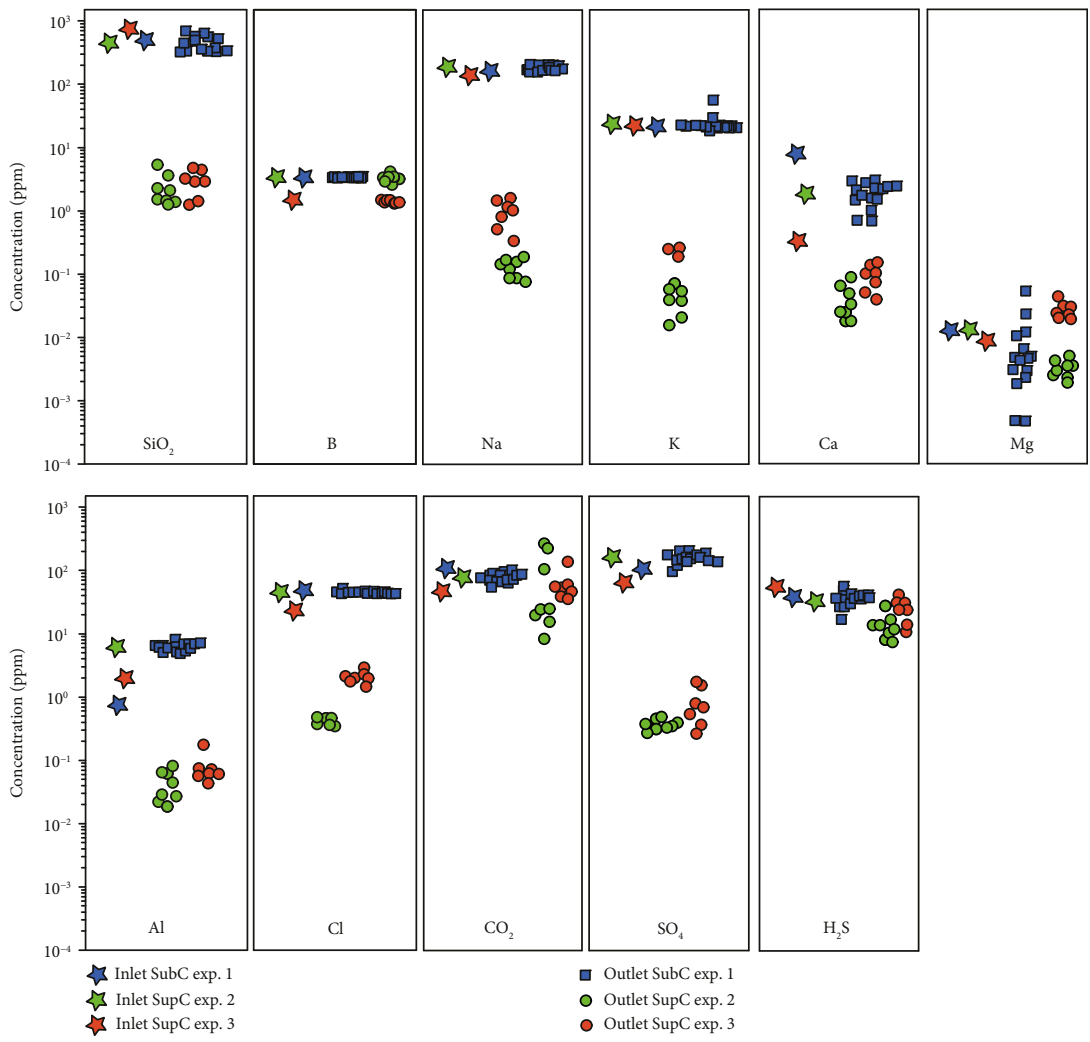

FIGURE 3: Elemental concentrations of inlet and outlet solutions of the experiments. Abbreviations: SubC and SupC refer to subcritical and supercritical conditions, respectively.
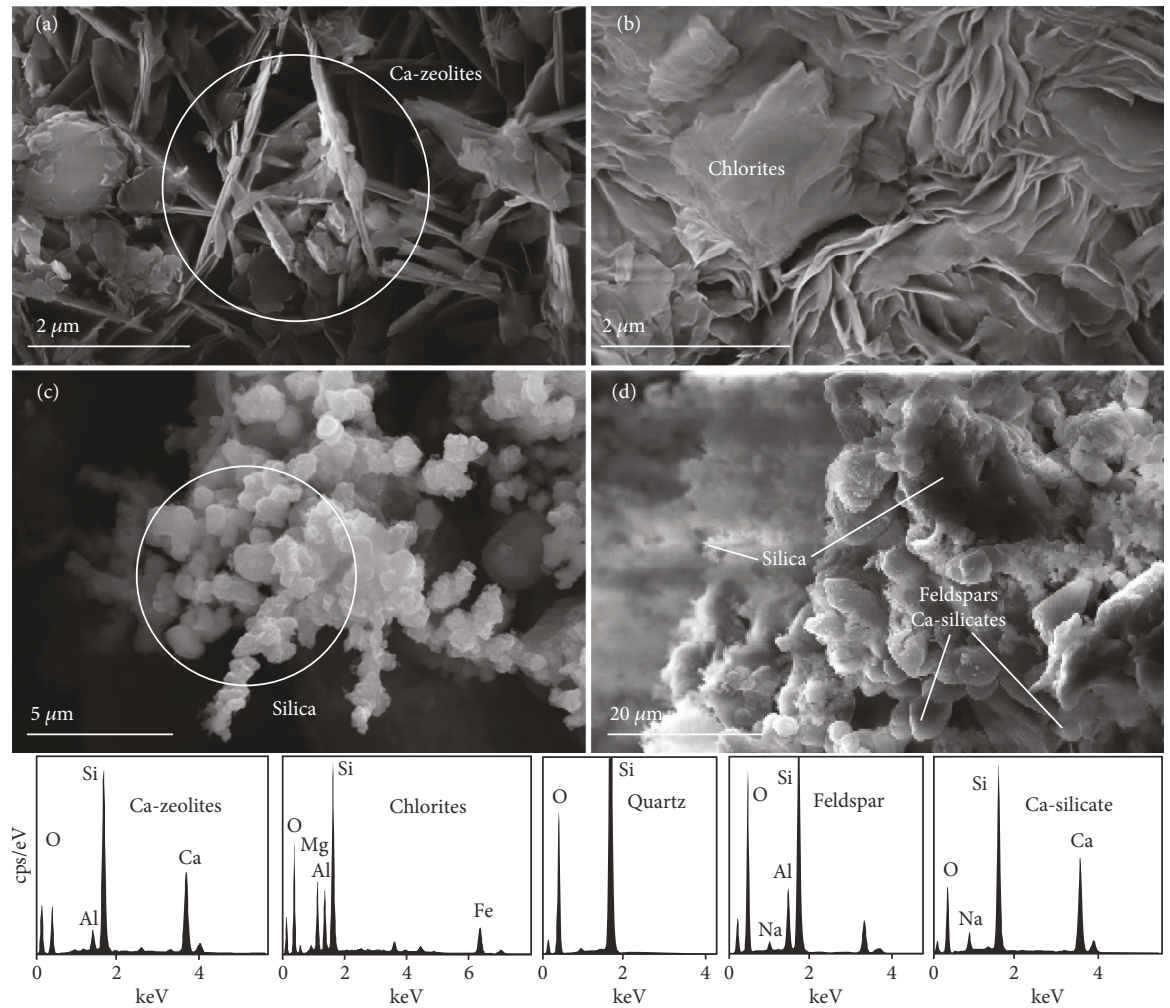

FIGURE 4: Selected SEM microphotographs and EDS spectras of minerals precipitated at both subcritical (a, b) and supercritical temperatures $(c, d)$. 

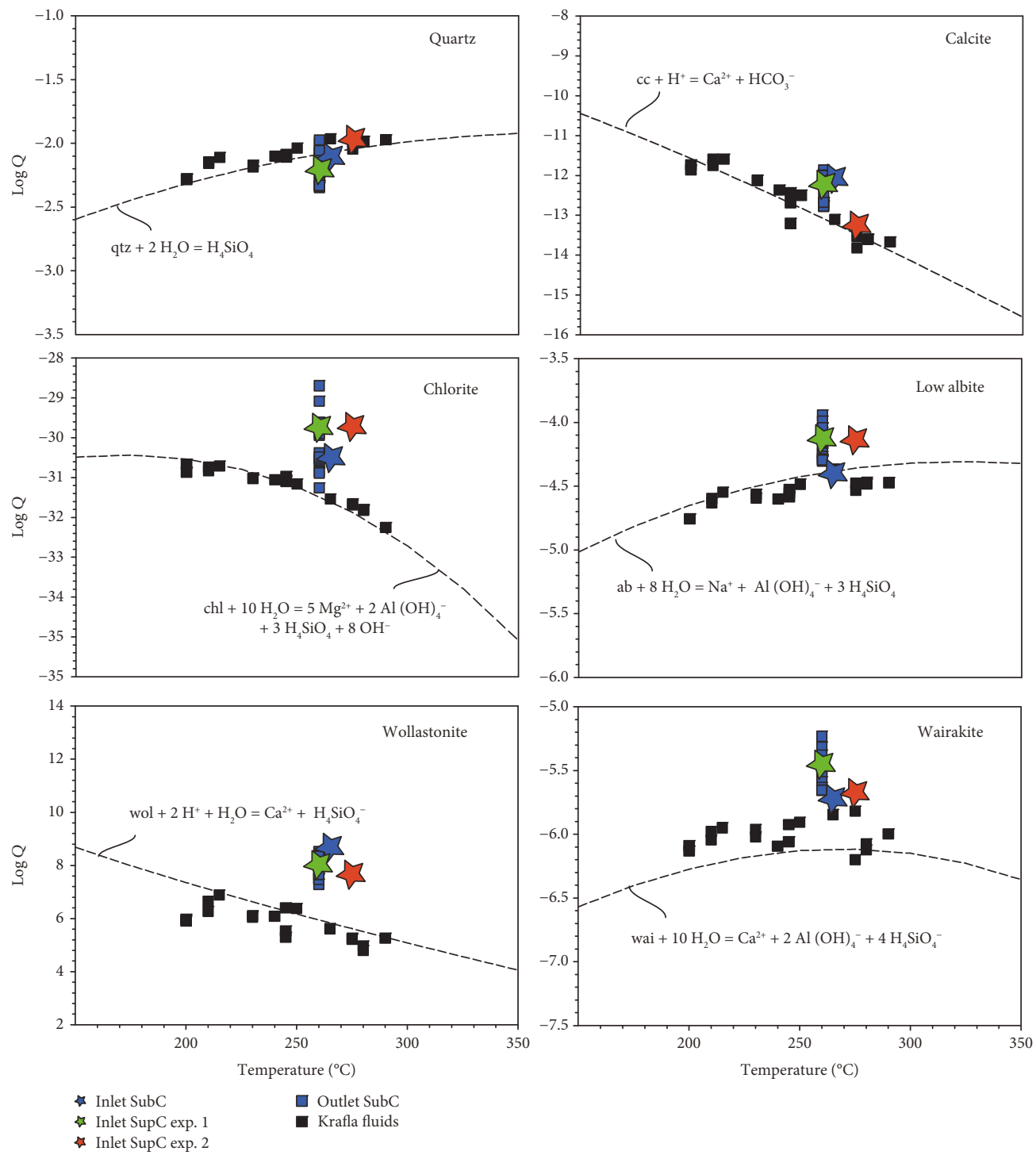

FIGURE 5: Mineral saturation state of selected minerals at subcritical conditions. The reaction quotients were calculated using the Phreeqc program [61] and the llnl.dat database. Also shown are mineral solubilities and the mineral reaction quotients for reservoir fluids at Krafla at the measured reservoir temperatures, both obtained from Gudmundsson and Arnórsson [41].

morphology of the deposits. The rod itself was imbedded into epoxy and cut parallel and perpendicular to the flow direction in the reactor and then polished.

2.2. Chemical Analyses. For the fluid samples, the $\mathrm{pH}$ was analyzed using a $\mathrm{pH}$ electrode and meter calibrated against commercial buffer solutions. Measurements of $\mathrm{CO}_{2}$ and $\mathrm{H}_{2} \mathrm{~S}$ concentrations were carried out using a modified alkalinity and $\mathrm{Hg}$-precipitation titration using dithizone as an indicator, respectively $[33,34]$. For $\mathrm{CO}_{2}$ determination, the samples from the supercritical reactor were collected into a base $(0.01 \mathrm{M} \mathrm{NaOH})$ to prevent degassing prior to analyses. For major elemental analyses $(\mathrm{Si}, \mathrm{B}, \mathrm{Na}, \mathrm{K}, \mathrm{Ca}, \mathrm{Mg}, \mathrm{Al}, \mathrm{Fe}$, $\mathrm{Cl}$, and $\mathrm{SO}_{4}$ ), the samples were filtered through a $0.2 \mu \mathrm{m}$ filter (cellulose acetate), acidified to $1 \%$ with $\mathrm{HNO}_{3}$ (Merck, Suprapur ${ }^{\circledR}$ ), followed by analysis using ICP-OES (Spectro Ciros Vision). The analytical precision of major element

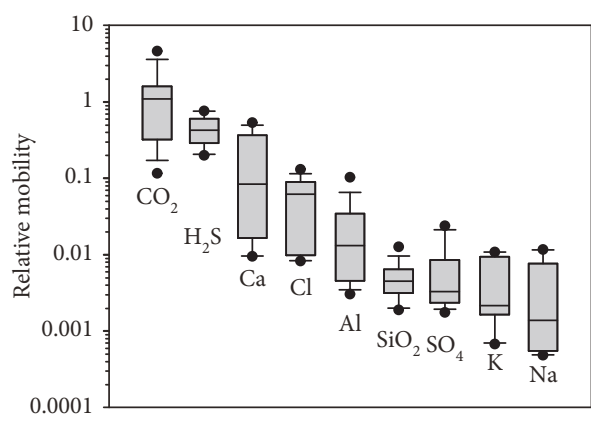

FIgURE 6: Relative mobility of major elements upon boiling of subcritical geothermal fluids by conductive heating to form supercritical fluids. Elements showing relative mobility close to 1 may be regarded as mobile, whereas elements with relative mobility of $<0.1$ are immobile. 
TABLE 4: Mineral-fluid reactions that describe how aqueous neutral species and ion activity ratios are presumably controlled at subcritical and supercritical conditions.

\begin{tabular}{|c|c|}
\hline Buffer reactions & Controlled neutral species and ion activity ratios \\
\hline \multicolumn{2}{|l|}{ Subcritical buffer reactions } \\
\hline $\mathrm{qtz}+2 \mathrm{H}_{2} \mathrm{O}=\mathrm{H}_{4} \mathrm{SiO}_{4}$ & $\mathrm{H}_{4} \mathrm{SiO}_{4}$ \\
\hline $\mathrm{py}+$ pyrr +2 pre $+\mathrm{H}_{2} \mathrm{O}=2 \mathrm{epi}+3 \mathrm{H}_{2} \mathrm{~S}$ & $\mathrm{H}_{2} \mathrm{~S}$ \\
\hline 4 pyrr $+2 \mathrm{pre}+2 \mathrm{H}_{2} \mathrm{O}=2 \mathrm{epi}+2 \mathrm{py}+3 \mathrm{H}_{2}$ & $\mathrm{H}_{2}$ \\
\hline $2 \mathrm{czo}+2 \mathrm{cc}+3 \mathrm{qtz}+2 \mathrm{H}_{2} \mathrm{O}=3 \mathrm{pre}+2 \mathrm{CO}_{2}$ & $\mathrm{CO}_{2}$ \\
\hline $1.5 \mathrm{pre}+2 \mathrm{H}^{+}=1.5 \mathrm{qtz}+1.5 \mathrm{czo}+2 \mathrm{H}_{2} \mathrm{O}+\mathrm{Ca}^{2+}$ & $\mathrm{Ca}^{2+} /\left(\mathrm{H}^{+}\right)^{2}$ \\
\hline $4.5 \mathrm{qtz}+\mathrm{czo}+2 \mathrm{Na}^{+}=0.5 \mathrm{pre}+2 \mathrm{alb}+\mathrm{Ca}^{2+}$ & $\mathrm{Ca}^{2+} /\left(\mathrm{Na}^{+}\right)^{2}$ \\
\hline $\mathrm{alb}+\mathrm{K}^{+}=\mathrm{mic}+\mathrm{Na}^{+}$ & $\mathrm{Na}^{+} / \mathrm{K}^{+}$ \\
\hline 0.67 epi +0.67 pyrr $+2 \mathrm{H}^{+}=0.33$ py +0.67 pre $+1.5 \mathrm{H}_{2} \mathrm{O}+\mathrm{Fe}^{2+}$ & $\mathrm{Fe}^{2+} /\left(\mathrm{H}^{+}\right)^{2}$ \\
\hline $\mathrm{czo}+2 \mathrm{H}_{2} \mathrm{O}+\mathrm{OH}^{-}=\mathrm{pre}+\mathrm{Al}(\mathrm{OH})_{4}^{-}$ & $\mathrm{Al}(\mathrm{OH})_{4}^{-} / \mathrm{OH}^{-}$ \\
\hline $\mathrm{chl}+3 \mathrm{wai}+5 \mathrm{Ca}^{2+}=4 \mathrm{pre}+3 \mathrm{qtz}+6 \mathrm{H}_{2} \mathrm{O}+5 \mathrm{Mg}^{2+}$ & $\mathrm{Mg}^{2+} / \mathrm{Ca}^{2+}$ \\
\hline \multicolumn{2}{|l|}{ Supercritical reactions } \\
\hline $\mathrm{qtz}=\mathrm{SiO}_{2}(\mathrm{~g})$ & $\mathrm{SiO}_{2}(\mathrm{~g})$ \\
\hline $\mathrm{NaCl}(\mathrm{s})+n \mathrm{H}_{2} \mathrm{O}=\mathrm{NaCl} \cdot n \mathrm{H}_{2} \mathrm{O}(\mathrm{g})$ & $\mathrm{Na}(\mathrm{NaCl})$ \\
\hline $\mathrm{KCl}(\mathrm{s})+n \mathrm{H}_{2} \mathrm{O}=\mathrm{NaCl} \cdot n \mathrm{H}_{2} \mathrm{O}(\mathrm{g})$ & $\mathrm{K}(\mathrm{KCl})$ \\
\hline $\mathrm{CaCl}_{2}(\mathrm{~s})+n \mathrm{H}_{2} \mathrm{O}=\mathrm{CaCl}_{2} \cdot n \mathrm{H}_{2} \mathrm{O}(\mathrm{g})$ & $\mathrm{Ca}\left(\mathrm{CaCl}_{2}\right)$ \\
\hline \multirow[t]{2}{*}{$\mathrm{MgCl}_{2}(\mathrm{~s})+n \mathrm{H}_{2} \mathrm{O}=\mathrm{CaCl}_{2} \cdot n \mathrm{H}_{2} \mathrm{O}(\mathrm{g})$} & $\operatorname{Mg}\left(\mathrm{MgCl}_{2}\right)$ \\
\hline & $\mathrm{Cl}$ (sum of $\mathrm{MCl}_{\mathrm{x}}(\mathrm{g})$ species) \\
\hline
\end{tabular}

analyses was based on repeated analysis of the GYG13 standard and was found to be $<3 \%$ at the $95 \%$ confidence level for all elements except Fe, where it was $\sim 14 \%$. The analytical precision for $\mathrm{pH}$ was \pm 0.05 .

The secondary mineral phases and the morphology of the solid products from the two reactors were determined using a HITACHI TM-3000 scanning electron microscope (SEM) with an accelerating voltage of $15 \mathrm{kV}$.

\section{Results}

3.1. Chemical Composition of the Outlet Solutions. The chemical compositions of the outlet solutions from the experiments are given in Table 3 and shown in Figure 3. The outlet solutions from the subcritical reactor (experiment 1 ) were mildly alkaline $\left(\mathrm{pH} 8.00-9.79\right.$ at $\left.21^{\circ} \mathrm{C}\right)$ with concentrations of $\mathrm{SiO}_{2}$ (325-674 ppm), B (3.35-3.48 ppm), Na (160-212 ppm), K (18.6-55.5 ppm), $\mathrm{Cl}(43.2-50.0 \mathrm{ppm}), \mathrm{CO}_{2}(55.5-99.0 \mathrm{ppm})$, $\mathrm{SO}_{4}$ (98-207 ppm), and $\mathrm{H}_{2} \mathrm{~S}$ (17.4-57.9 ppm) similar to concentrations in the inlet solution (Table 3). Concentrations of $\mathrm{Ca}(0.69-3.04 \mathrm{ppm})$ were significantly lower than corresponding concentrations in the inlet solution $(7.61 \mathrm{ppm})$ whereas $\mathrm{Al}$ concentrations (4.86-8.04 ppm) were significantly higher in the outlet solutions than in the inlet solution $(0.84 \mathrm{ppm})$. The outlet solutions from the supercritical reactors were mildly acidic (pH3.24 to 5.06 at $21^{\circ} \mathrm{C}$ ). In experiment 2, concentrations of $\mathrm{SiO}_{2}$ (1.3-5.3 ppm), Na (0.1-0.2 ppm), K (<0.07 ppm), Ca (0.02-0.09 ppm), Al (0.018$0.081 \mathrm{ppm}), \mathrm{Cl}(0.35-0.48 \mathrm{ppm})$, and $\mathrm{SO}_{4}(0.27-0.49 \mathrm{ppm})$ were considerably lower than the corresponding concentrations of the inlet solution from the subcritical reactor. Concentrations of $\mathrm{B}(2.58-4.16 \mathrm{ppm}), \mathrm{CO}_{2}(8.32-225 \mathrm{ppm})$, and $\mathrm{H}_{2} \mathrm{~S}$ (7.56-28.0 ppm) of the outlet solution did not differ much from the inlet solution (Figure 3 ). In experiment 3 , similar trends were observed. Concentrations of $\mathrm{SiO}_{2}(1.2-$ $4.6 \mathrm{ppm}), \mathrm{Na}(0.4-1.6 \mathrm{ppm}), \mathrm{K} \quad(<0.3 \mathrm{ppm}), \mathrm{Ca} \quad(0.06-$ $0.17 \mathrm{ppm}), \mathrm{Al}(0.041-0.17 \mathrm{ppm}), \mathrm{Cl}(1.41-2.85 \mathrm{ppm})$, and $\mathrm{SO}_{4}(0.26-1.74 \mathrm{ppm})$ were substantially lower than the corresponding concentrations in the inlet solution (Figure 3). Again, concentrations of $\mathrm{B}(1.30-1.47 \mathrm{ppm}), \mathrm{CO}_{2}$ (35.4$135 \mathrm{ppm}$ ), and $\mathrm{H}_{2} \mathrm{~S}$ (10.7-40.0 ppm) of the outlet solutions did not differ significantly from the inlet solution. Concentrations of $\mathrm{Fe}$ and $\mathrm{Mg}$ in all fluid samples were close to the detection limit and/or affected by contamination and were not considered further in this study.

3.2. Mineralogy and Chemical Composition of the Solid Products. Secondary minerals associated with alteration of the basaltic glass at subcritical temperatures $\left(260^{\circ} \mathrm{C}\right)$ occurred mainly as thin layers on the surface of the primary glass. The main secondary minerals identified were chlorites, Na-Ca zeolite (wairakite), Ca-silicate (wollastonite), and calcite (Figure 4(a) and (b)). For supercritical temperatures, abundant white deposits on the steel rod were observed, mainly composed of quartz (Figure 4(c)). Microcline and wollastonite were found in minor amounts. Thick deposits (1-2 mm) occurred on the part of the rod located closest to the inlet of the reactor. Here, silicate layers were most massive closest 
to the rod, becoming highly porous with increasing distance from the rod. Towards the outlet of the reactor, quartz precipitates occurred as amorphous silica (spheres with $<1 \mu \mathrm{m}$ in diameter) interconnected with fine silica branches up to $10 \mu \mathrm{m}$ long (Figure 4(d)).

\section{Discussion}

4.1. Geochemistry of Subcritical Geothermal Fluids. Studies of alteration mineralogy and fluid composition in geothermal systems show that equilibrium is closely approached between the geothermal fluids and secondary minerals formed in the systems, except for mobile elements such as $\mathrm{Cl}$ [35-39]. At Krafla, the most common secondary minerals identified include calcite, quartz, epidote, various clays, chlorite, feldspars, and pyrite. Anhydrite, prehnite, actinolite, wollastonite, garnet, pyrrhotite, and various zeolites, including wairakite, have also been observed [40]. Previous studies on mineralfluid interaction at Krafla have demonstrated that the major fluid components were in equilibrium with these minerals, which in turn control the fluid composition at depth (Figure 5) [41].

Our experimental results indicate a similar process of mineral-fluid interaction at subcritical temperatures, with formation of secondary minerals upon interaction of geothermal water with the primary basaltic rock and glass. The calculated saturation indices with respect to commonly observed secondary minerals revealed near-equilibrium between the fluids and quartz, whereas supersaturation occurs with respect to calcite, chlorite, feldspars, wollastonite, and zeolites (Figure 5). Supersaturation may have resulted from high initial concentrations in the inlet experimental solutions relative to the equilibrium composition at $260^{\circ} \mathrm{C}$ and experimental durations of hours, compared to residence times of fluids in natural geothermal systems like at Krafla that are in the order of months to years [42, 43]. We conclude that the chemical composition of geothermal fluids at subcritical temperatures is controlled by nearequilibrium with secondary minerals. This agrees with previous findings [35-39, 41].

4.2. Supercritical Fluid Formation, Fluid-Rock Interaction, and Control of Elemental Transport. The solubility of mineral-forming elements and salts including $\mathrm{Si}, \mathrm{Ca}, \mathrm{K}$, $\mathrm{Na}$, and $\mathrm{Cl}$ is orders of magnitude lower in supercritical fluids compared to subcritical fluids and has been observed to decrease with decreasing fluid density [44-46]. Indeed, a recent modeling study of the formation of supercritical fluid by conductive boiling of subcritical fluids revealed that the process is expected to result in mineral deposition dominated by silica, aluminum silicates, and salts around the heat source [31]. In contrast, volatile elements like $\mathrm{B}, \mathrm{CO}_{2}$, and $\mathrm{H}_{2} \mathrm{~S}$ are expected to partition into the vapor phase upon boiling, resulting in insignificant concentration changes in the total fluid.

Elemental behavior upon conductive heating of subcritical liquid water to form supercritical fluid may be demonstrated from the elemental relative mobilities (RM), given by the elemental concentration $\left(m_{i}\right)$ ratio between

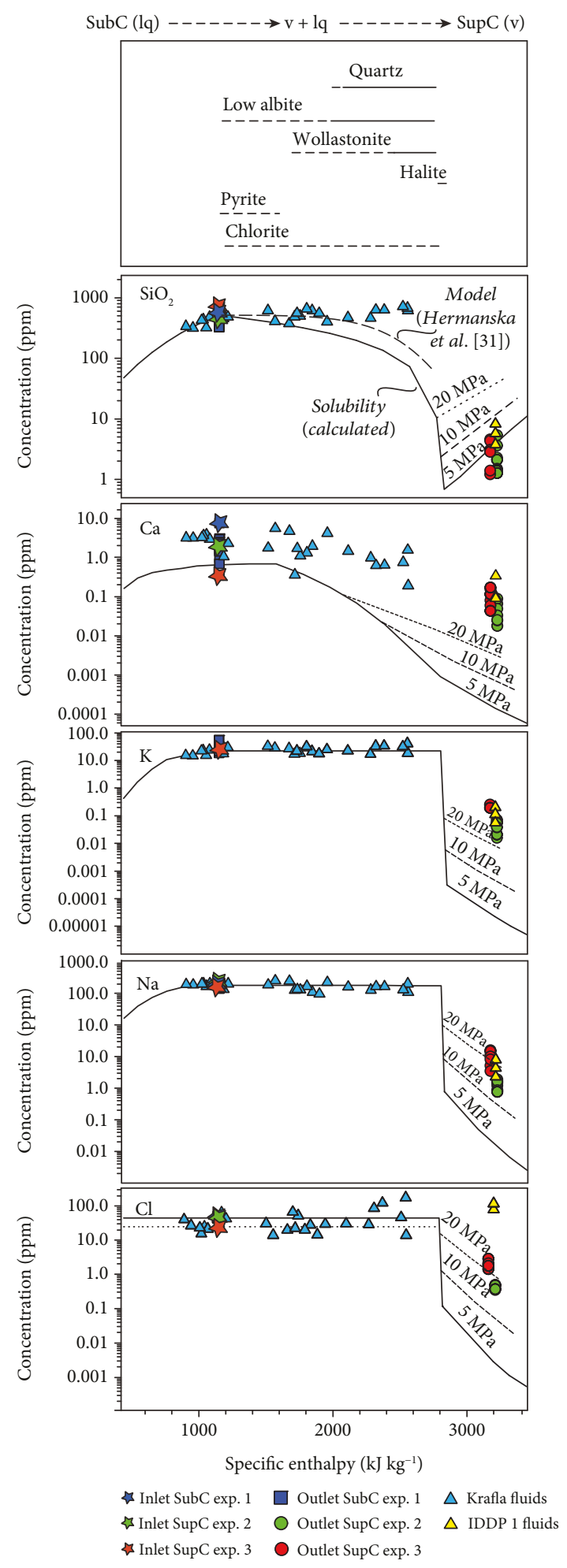

FIgURE 7: The concentration of subcritical and supercritical geothermal fluids observed in the experiments and at Krafla, Iceland [31, 41]. Also shown are predicted equilibrium concentrations assuming mineral-fluid equilibria at subcritical conditions [41, 47] as well as quartz and salt equilibrium solubility concentrations in supercritical water [44-46]. 


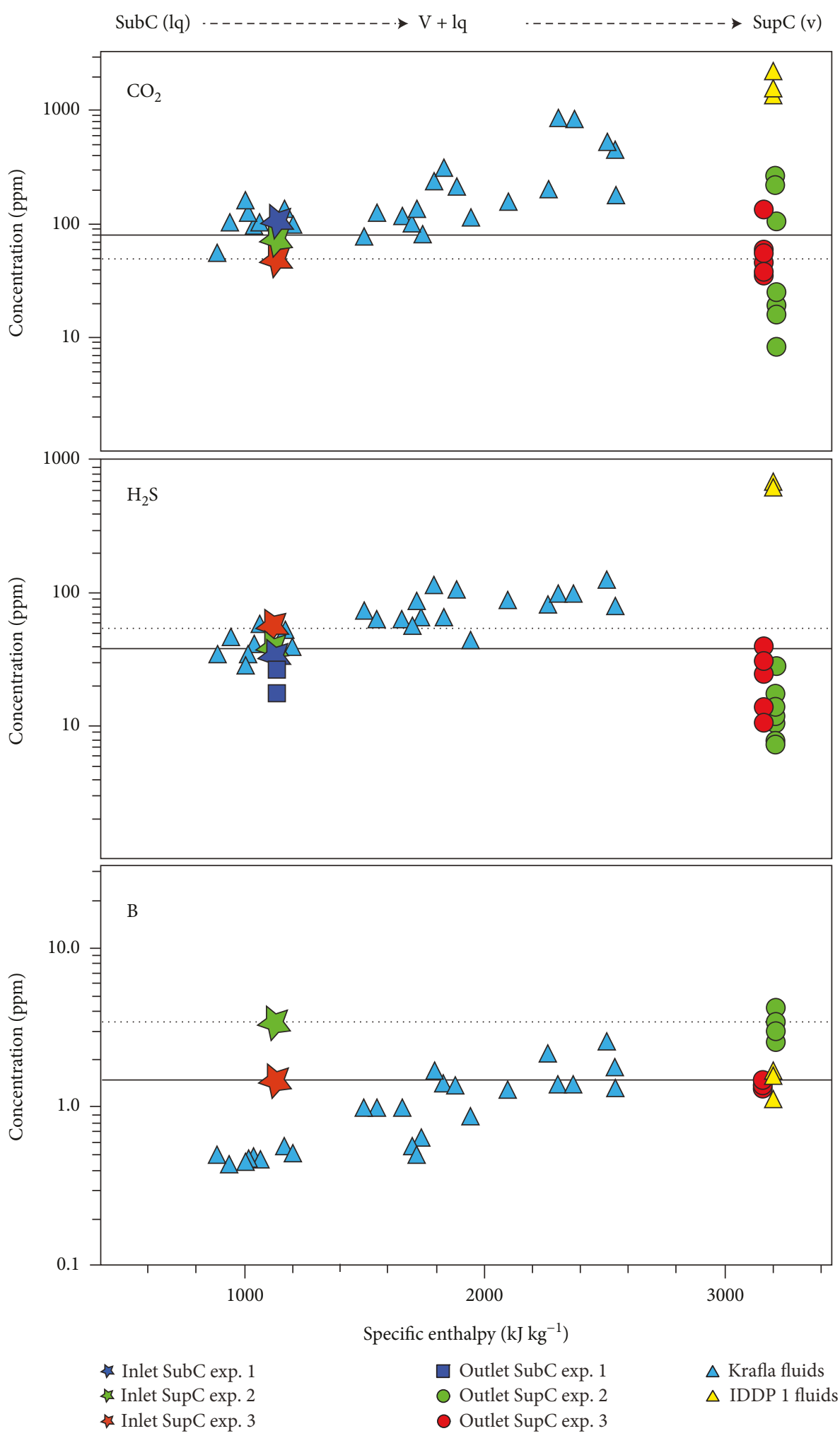

Figure 8: Concentrations of $\mathrm{B}, \mathrm{CO}_{2}$, and $\mathrm{H}_{2} \mathrm{~S}$ in the subcritical to supercritical fluids. Experimental results, concentrations in subcritical geothermal reservoir fluids at Krafla and the IDDP-1 fluid discharge composition [31, 41], and concentration trends predicted by previous geochemical modeling calculations [31]. 
TABLE 5: Comparison of measured and modeled geothermal fluids at Krafla. Concentrations are in ppm.

\begin{tabular}{|c|c|c|c|c|c|c|}
\hline & \multicolumn{2}{|c|}{ Subcritical fluid } & \multirow[b]{2}{*}{ Experiment w $37^{\mathrm{a}}$} & \multicolumn{2}{|c|}{ Supercritical fluid } & \multirow[b]{2}{*}{ Model $^{\mathrm{c}}$} \\
\hline & Experiment $^{\mathrm{a}}$ & Krafla $^{\mathrm{b}}$ & & Experiment $\mathrm{w} 17^{\mathrm{a}}$ & IDDP- $1^{\mathrm{C}}$ & \\
\hline$t\left({ }^{\circ} \mathrm{C}\right)$ & 260 & 295 & 420 & 400 & 440 & \\
\hline $\mathrm{SiO}_{2}$ & $453 \pm 121$ & 659 & $2.4 \pm 1.4$ & $2.9 \pm 1.3$ & 6.0 & 3.2 \\
\hline B & $3.41 \pm 0.05$ & 1.23 & $3.30 \pm 0.46$ & $1.39 \pm 0.06$ & 1.41 & 1.39 \\
\hline $\mathrm{Na}$ & $181 \pm 18$ & 178 & $0.13 \pm 0.04$ & $0.99 \pm 0.46$ & 0.51 & 168 \\
\hline $\mathrm{K}$ & $21.1 \pm 9.1$ & 40.9 & $0.04 \pm 0.02$ & $0.23 \pm 0.04$ & 0.12 & 31.8 \\
\hline $\mathrm{Ca}$ & $1.91 \pm 0.76$ & 1.18 & $0.04 \pm 0.03$ & $0.10 \pm 0.05$ & 0.16 & 0.0002 \\
\hline $\mathrm{Mg}$ & $0.009 \pm 0.013$ & 0.001 & $0.003 \pm 0.001$ & $0.026 \pm 0.008$ & 0.024 & 0.000001 \\
\hline $\mathrm{Fe}$ & $0.044 \pm 0.036$ & 0.036 & $0.04 \pm 0.01$ & $0.12 \pm 0.06$ & 5.25 & 0.004 \\
\hline $\mathrm{Al}$ & $6.20 \pm 0.79$ & 1.27 & $0.04 \pm 0.02$ & $0.08 \pm 0.04$ & 0.054 & 0.001 \\
\hline $\mathrm{Cl}$ & $44.8 \pm 1.6$ & 112 & $0.41 \pm 0.06$ & $1.99 \pm 0.44$ & 105 & 109 \\
\hline $\mathrm{CO}_{2}$ & $76.9 \pm 12.5$ & 858 & $87 \pm 104$ & $60.5 \pm 34.2$ & 1637 & 1628 \\
\hline $\mathrm{SO}_{4}$ & $157 \pm 29$ & 127 & $0.37 \pm 0.07$ & $0.84 \pm 0.57$ & 32.7 & 4.13 \\
\hline $\mathrm{H}_{2} \mathrm{~S}$ & $37.3 \pm 9.6$ & 266 & $13.9 \pm 6.5$ & $25.1 \pm 10.2$ & 630 & 395 \\
\hline
\end{tabular}

${ }^{\mathrm{a}}$ An average from the experimental runs (Table 3). ${ }^{\mathrm{b}}$ From Kaasalainen and Stefánsson [64]. ${ }^{\mathrm{c}}$ From Heřmanská et al. [31].

the inlet and outlet solution relative to a mobile element like B:

$$
\mathrm{RM}=\frac{\left(m_{i} / m_{B}\right)_{\text {outlet }}}{\left(m_{i} / m_{B}\right)_{\text {inlet }}}
$$

The results demonstrate that volatile elements separate from the major rock-forming elements upon boiling of subcritical fluids to supercritical temperatures (Figure 6). Boron, $\mathrm{CO}_{2}$, and $\mathrm{H}_{2} \mathrm{~S}$ partition into the vapor phase, whereas nonvolatile elements like $\mathrm{Si}, \mathrm{Ca}, \mathrm{Na}, \mathrm{K}, \mathrm{Al}, \mathrm{Cl}$, and $\mathrm{SO}_{4}$ are precipitated into the observed secondary minerals, mainly silica, aluminum silicates, and chlorides. Chloride may also precipitate into salts like halite and sylvite (Figure 4 ). In this way, $<1-10 \%$ of these elements are quantitatively removed from the initial concentration of the subcritical fluids.

The elemental concentrations can be further compared with the mineral-fluid equilibrium conditions considered to control their concentrations. At subcritical conditions, these reactions and equilibrium conditions are well established and include single mineral reactions as well as mineral-pair reactions [41] (Table 4). In order to calculate the individual elemental concentrations from these mineral-fluid equilibria buffers, further knowledge of the reservoir $\mathrm{pH}$ is needed. Here, $\mathrm{pH}$ conditions for Krafla fluids were adopted from Stefánsson and Arnórsson [47]. Experimental results are compared with calculated equilibrium compositions in Figure 7. Both experimental results and calculated equilibrium compositions showed good agreement between the two demonstrating a mineral-fluid equilibria control on the subcritical fluid compositions.

At supercritical conditions, it is less certain what processes control the fluid composition. Mineral solubilities are poorly known except for quartz and some common salts [44-46], therefore the experimental results are compared with the calculated solubility of quartz $\left(\mathrm{SiO}_{2}\right)$ and simple salts $\left(\mathrm{NaCl}, \mathrm{KCl}\right.$, and $\left.\mathrm{CaCl}_{2}\right)$, shown in Figure 7. Excellent agreement was observed for silica, suggesting that equilibrium between quartz and the supercritical fluid controls Si concentration in the fluid. In the case of other mineral-forming elements, concentrations obtained in the experiments were similar to or somehow higher to the calculated equilibrium concentrations of the salts. The elemental concentrations of these salts in the supercritical fluids may be influenced by a combination of different mineral solubilities including salts, oxides, and aluminum silicates. In contrast, the concentration of volatile elements like B, C, and S (Figure 8) remained unchanged in the fluid from subcritical to supercritical conditions, which is in agreement with previous geochemical modeling calculations [31].

4.3. Comparison of Experimental and Modeling Results with IDDP-1 Fluids. Experimental conductive boiling of a subcritical geothermal fluid to form supercritical fluid decreased mineral-forming element concentrations, whereas concentrations of volatile components remained mostly unchanged. Similar trends were observed in the elemental concentrations measured in the IDDP-1 supercritical fluid discharge when compared to subcritical fluids at Krafla (Table 5). However, direct comparison of experimental and IDDP-1 fluids shows that most concentrations of mineral-forming elements ( $\mathrm{Si}$, $\mathrm{Na}, \mathrm{K}$, and $\mathrm{Ca}$ ) fall into a similar range, whereas $\mathrm{Cl}$ and volatile $\left(\mathrm{CO}_{2}, \mathrm{H}_{2} \mathrm{~S}\right)$ concentrations differed significantly (Table 5). Concentrations of $\mathrm{Cl}$ at laboratory conditions were considerably lower than concentrations observed in the IDDP-1 discharge. Low concentrations of $\mathrm{Cl}$ in experimental fluids were caused by precipitation of minor amounts of salts (e.g., halite) in the very late stage of the boiling process. High concentrations of $\mathrm{Cl}$ and other volatile elements such as $\mathrm{C}$ and $\mathrm{S}$ in the IDDP-1 fluids could be attributed to minor magmatic degassing [48-50]. The experimental results thus support previous findings that supercritical IDDP-1 


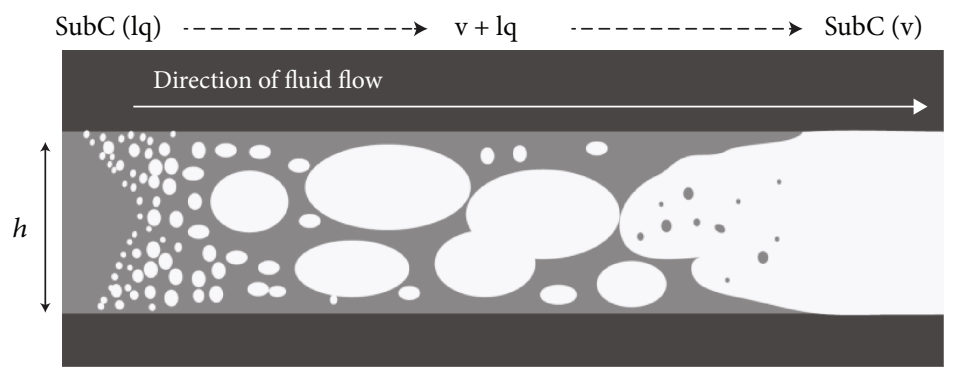

(a)

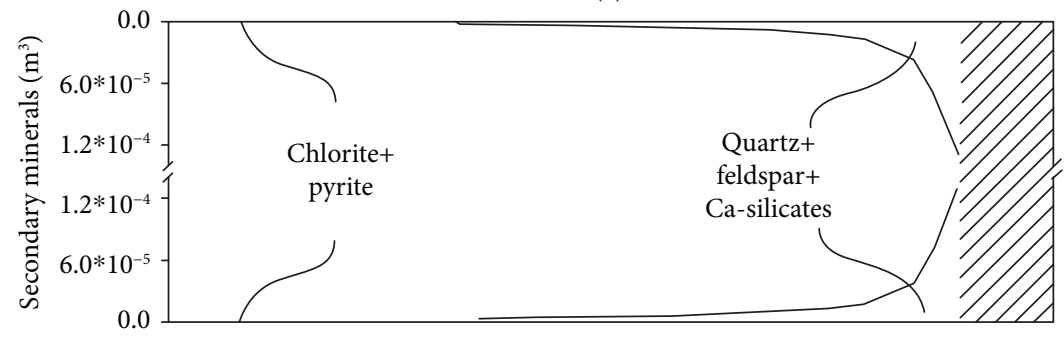

(b)

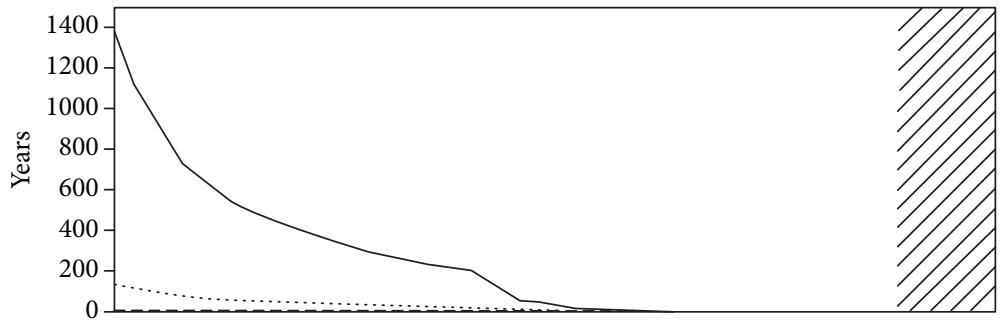

Fluid mass flux (Q)

$-10^{-6} \mathrm{~kg} \mathrm{~m}^{-2} \mathrm{~s}^{-1}$
$\ldots \ldots 10^{-5} \mathrm{~kg} \mathrm{~m}^{-2} \mathrm{~s}^{-1}$
$-\ldots-10^{-4} \mathrm{~kg} \mathrm{~m}^{-2} \mathrm{~s}^{-1}$

for $h=0.05 \mathrm{~mm}$

(c)

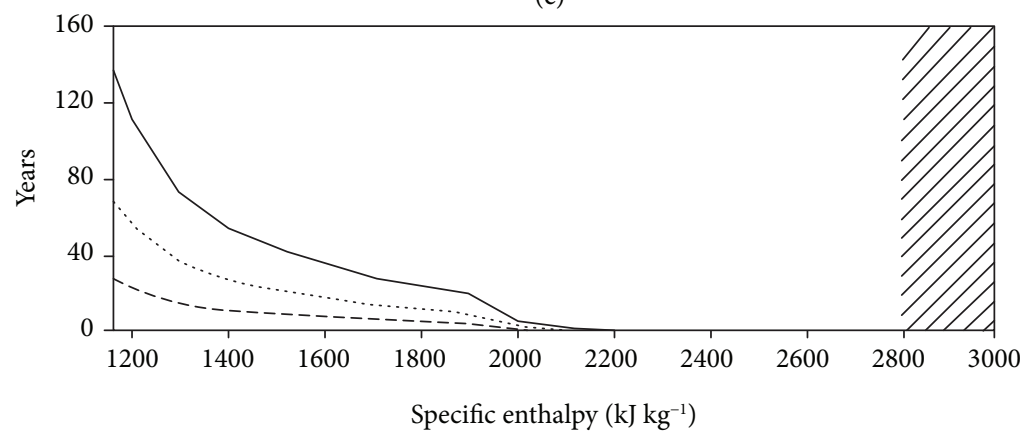

Fracture width $(h)$

$0.050 \mathrm{~mm}$

.... $0.025 \mathrm{~mm}$

- - $0.010 \mathrm{~mm}$

for $Q=10^{-5} \mathrm{~m}^{-2} \mathrm{~s}^{-1}$

(d)

FIGURE 9: Mechanism of conductive boiling of subcritical fluids in cracks near the brittle-ductile transition (BDT). (a) Conductive boiling of a subcritical fluid to supercritical conditions along a single crack. (b) Volumes of secondary minerals (from Heřmanská et al. [31]) formed upon conductive boiling as a function of specific enthalpy along a crack. (c) Time for closure of a crack with a width of $0.05 \mathrm{~mm}$ as a function of specific enthalpy and fluid mass flux. Values for the range of fluid mass flux are taken from Norton and Knight [54]. (d) Time for closure of a crack with variable width based on permeability values of Norton and Knapp [53], Lamur et al. [51], and Watanabe et al., [52] using an average fluid mass flux of $10^{-5} \mathrm{~kg} \mathrm{~m}^{-2} \mathrm{~s}^{-1}$ [54]. Closure of the crack accelerates as soon as quartz starts to precipitate. 
fluids likely form by conductive heating of subcritical geothermal reservoir fluids of meteoric water origin with minor input of magmatic gases [31, 48, 50]. Our experiments, in combination with geochemical modeling [31], revealed that varying the initial concentrations of volatile elements $(C, S$, and $\mathrm{B}$ ) in the reservoir geothermal fluid does not affect the chemical composition of the supercritical fluid nor the alteration mineralogy, due to early partitioning of volatile elements into the vapor (Figure 8).

4.4. Mechanism of Boiling in Cracks and Implications for Exploitation of Supercritical Resources. Our experiments suggest that quartz and other silicates such as feldspar and wollastonite are the dominant secondary mineral phases that precipitate upon conductive boiling of subcritical fluids to form supercritical fluids. Boiling of $1 \mathrm{~kg}$ of subcritical fluids from Krafla has been modeled to produce $\sim 50 \mathrm{~cm}^{3}$ of silica [31], and using such results, the time required for complete closure of cracks by secondary mineral formation can be calculated (Figure 9). The permeability in volcanic geothermal systems like Krafla has been shown to range typically from $10^{-14}$ to $10^{-16} \mathrm{~m}^{2}$, which can be equated to a single crack with a width of up to $0.05 \mathrm{~mm}$ cutting each cubic meter in the system [51-53]. Based on an average fluid mass flux of $10^{-5} \mathrm{~kg} \mathrm{~m}^{-2} \mathrm{~s}^{-1}$ [54], conductive boiling of a subcritical fluid to supercritical conditions could lead to the complete closure of a 0.01 to $0.05 \mathrm{~mm}$ wide crack over a time period as short as a few hours or as long as $\sim 140$ years (Figure 9). These calculated time scales are in line with previous findings on permeability reduction in geothermal systems [25, 30, 32, 55-58]. However, the calculations should be considered as a simplification of real conditions. Mineral deposition was assumed to be immediate and independent of fluid flow, and possible reduced fluid flow upon decreased permeability associated with the mineral deposition was not considered. Formation of supercritical fluids may thus contribute to silica deposits, for example, as observed at the IDDP-1 well orifices [16]. However, such scaling will not occur during the supercritical fluid condensation as supercritical fluids exhibit low concentrations in mineral-forming elements (Figure 7).

\section{Conclusions}

The chemical and mineralogical changes associated with supercritical fluid formation by conductive heating and boiling of subcritical geothermal fluids were studied experimentally. Our results showed that the chemical composition of geothermal fluids at subcritical temperatures is controlled by near-equilibrium between the geothermal fluids and secondary minerals, except for mobile elements like $\mathrm{Cl}$, which is in line with previous studies [35-39]. Upon conductive heating and boiling of such fluids to form supercritical fluids having a temperature $>400^{\circ} \mathrm{C}$, rock-forming elements like $\mathrm{Si}, \mathrm{Na}, \mathrm{K}, \mathrm{Ca}, \mathrm{Mg}$, and $\mathrm{Cl}$ are quantitatively deposited into silicate, aluminum silicate, and salt deposits. In contrast, volatile element concentrations like $\mathrm{CO}_{2}, \mathrm{H}_{2} \mathrm{~S}$, and $\mathrm{B}$ remained unchanged. The observed concentrations of the nonvolatile elements are similar to those predicted from the solubility of quartz $\left(\mathrm{SiO}_{2}\right)$ and salts $\left(\mathrm{NaCl}, \mathrm{KCl}\right.$, and $\left.\mathrm{CaCl}_{2}\right)$ suggesting that reactions between these solids and the fluid influence and even control the elemental concentrations in the supercritical fluid. Similar concentration trends were observed for the IDDP-1 supercritical and subcritical geothermal fluids at Krafla, Iceland, and have been predicted from geochemical modeling [31]. The experimental results further support findings that the supercritical IDDP-1 fluids likely form by conductive heating of subcritical geothermal fluids of meteoric origin, with minor input of magmatic gases [31, 48, 50]. Such fluids may be suitable for power production.

\section{Data Availability}

The experimental data used to support the findings of this study are included within the article. The data from the Krafla geothermal field are from previously reported studies and datasets, which have been cited.

\section{Disclosure}

Preliminary results of selected parts of this study were previously presented during the Goldschmidt conference in Boston in 2018 [57].

\section{Conflicts of Interest}

The authors declare that there are no conflicts of interest regarding the publication of this paper.

\section{Acknowledgments}

We would like to thank Ríkey Kjartansdóttir, Andri Ísak Thórhallsson, and Helgi Arnar Alfreðsson for their valuable help. This work was funded by the Swiss National Science Foundation (CRSII2_1418431/1, Sinergia COTHERM), Georg (11-04-003), and The Energy Research Fund of Landsvirkjun in 2018 and 2019.

\section{References}

[1] D. O. Hayba and S. E. Ingebritsen, "Multiphase groundwater flow near cooling plutons," Journal of Geophysical Research: Solid Earth, vol. 102, no. B6, pp. 12235-12252, 1997.

[2] S. K. Sanyal and J. W. Morrow, "Success and the learning curve effect in geothermal well drilling," in Proceedings Thirty-Seventh Workshop on Geothermal Reservoir Engineering, Stanford, California, 2012.

[3] A. Richter, Global geothermal capacity reaches 14,369 MW top 10 geothermal countries, Oct 2018, Think GeoEnergy Geothermal Energy News, 2018.

[4] G. Ó. Friðleifsson, W. A. Elders, and A. Albertsson, "The concept of the Iceland Deep Drilling Project," Geothermics, vol. 49, pp. 2-8, 2014.

[5] L. Haar, J. S. Gallagher, and G. S. Kell, NBS/NRC steam tables thermodynamic and transport properties and computer programs for vapor and liquid states of water in SI units, Hemisphere Publishing, Washington, DC, USA, 1984.

[6] A. Liebscher and C. A. Heinrich, "Fluid-fluid interactions in the Earth's lithosphere," Reviews in Mineralogy and Geochemistry, vol. 65, no. 1, pp. 1-13, 2007. 
[7] S. Scott, T. Driesner, and P. Weis, "Geologic controls on supercritical geothermal resources above magmatic intrusions," Nature Communications, vol. 6, no. 1, article 7837, 2015.

[8] S. Scott, T. Driesner, and P. Weis, "The thermal structure and temporal evolution of high-enthalpy geothermal systems," Geothermics, vol. 62, pp. 33-47, 2016.

[9] B. Mack Kennedy and A. H. Truesdell, "The northwest Geysers high-temperature reservoir: evidence for active magmatic degassing and implications for the origin of the Geysers geothermal field," Geothermics, vol. 25, no. 3, pp. 365-387, 1996.

[10] J. B. Lowenstern, D. Bergfeld, W. C. Evans, and A. G. Hunt, "Origins of geothermal gases at Yellowstone," Journal of Volcanology and Geothermal Research, vol. 302, pp. 87-101, 2015.

[11] A. Stefánsson, "Gas chemistry of Icelandic thermal fluids," Journal of Volcanology and Geothermal Research, vol. 346, pp. 81-94, 2017.

[12] T. Reinsch, P. Dobson, H. Asanuma, E. Huenges, F. Poletto, and B. Sanjuan, "Utilizing supercritical geothermal systems: a review of past ventures and ongoing research activities," Geothermal Energy, vol. 5, no. 1, p. 16, 2017.

[13] W. A. Elders, G. Ó. Friðleifsson, and A. Albertsson, "Drilling into magma and the implications of the Iceland Deep Drilling Project (IDDP) for high-temperature geothermal systems worldwide," Geothermics, vol. 49, pp. 111-118, 2014.

[14] G. Axelsson, T. Egilson, and S. S. Gylfadóttir, "Modelling of temperature conditions near the bottom of well IDDP-1 in Krafla, northeast Iceland," Geothermics, vol. 49, pp. 49-57, 2014.

[15] T. Hauksson and S. H. Markusson, "IDDP-1 flow test 20102012," Landsvirkjun report, LV-2013-050, National Power Company of Iceland, Reykjavik, 2013.

[16] T. Hauksson, S. Markusson, K. Einarsson et al., "Pilot testing of handling the fluids from the IDDP-1 exploratory geothermal well, Krafla, N.E. Iceland," Geothermics, vol. 49, pp. 7682, 2014.

[17] G. Ó. Friðleifsson, W. A. Elders, R. A. Zierenberg et al., "The Iceland Deep Drilling Project $4.5 \mathrm{~km}$ deep well, IDDP-2, in the seawater-recharged Reykjanes geothermal field in SW Iceland has successfully reached its supercritical target," Scientific Drilling, vol. 23, pp. 1-12, 2017.

[18] E. Bali, L. E. Aradi, Á. Szabó, Cs. Szabó, G. Ó. Friðleifsson, and R. Zierenberg, "Fluid composition in the deepest part of the IDDP-2 deep borehole in Iceland based on fluid inclusions," in Acta Mineralogica-Petrographica Abstract series, ECROFI XXV abstract book, p. 16, Department of Mineralogy, Geochemistry and Petrology, University of Szeged, 2019.

[19] R. Brooks Hanson, "The hydrodynamics of contact metamorphism," GSA Bulletin, vol. 107, no. 5, pp. 595-611, 1995.

[20] R. B. Hanson, "Hydrodynamics of magmatic and meteoric fluids in the vicinity of granitic intrusions," in Special Paper 315: The Third Hutton Symposium on the Origin of Granites and Related Rocks, pp. 251-259, Geological Society of America, 1996.

[21] P. Weis, T. Driesner, and C. A. Heinrich, "Porphyry-copper ore shells form at stable pressure-temperature fronts within dynamic fluid plumes," Science, vol. 338, no. 6114, pp. 16131616, 2012.

[22] J. Hasenclever, S. Theissen-Krah, L. H. Rüpke et al., "Hybrid shallow on-axis and deep off-axis hydrothermal circulation at fast-spreading ridges," Nature, vol. 508, no. 7497, pp. 508$512,2014$.
[23] P. Weis, "The dynamic interplay between saline fluid flow and rock permeability in magmatic-hydrothermal systems," Geofluids, vol. 15, no. 1-2, pp. 350-371, 2015.

[24] T. P. Fischer and G. Chiodini, "Chapter 45 - Volcanic, magmatic and hydrothermal gases," in The Encyclopedia of Volcanoes(Second edition), H. Sigurdsson, Ed., pp. 779-797, Academic Press, Amsterdam, 2015.

[25] R. O. Fournier, "Hydrothermal processes related to movement of fluid from plastic into brittle rock in the magmaticepithermal environment," Economic Geology, vol. 94, no. 8, pp. 1193-1211, 1999.

[26] R. O. Foumier, "The transition from hydrostatic to greater than hydrostatic fluid pressure in presently active continental hydrothermal systems in crystalline rock," Geophysical Research Letters, vol. 18, no. 5, pp. 955-958, 1991.

[27] A. Okamoto, H. Saishu, N. Hirano, and N. Tsuchiya, "Mineralogical and textural variation of silica minerals in hydrothermal flow-through experiments: implications for quartz vein formation," Geochimica et Cosmochimica Acta, vol. 74, no. 13, pp. 3692-3706, 2010.

[28] A. Okamoto, T. Kikuchi, and N. Tsuchiya, "Mineral distribution within polymineralic veins in the Sanbagawa belt, Japan: implications for mass transfer during vein formation," Contributions to Mineralogy and Petrology, vol. 156, no. 3, pp. 323-336, 2008.

[29] H. Saishu, A. Okamoto, and N. Tsuchiya, "The effect of Al and $\mathrm{Na}$ on the precipitation rate of silica minerals: hydrothermal flow-through experiments at $430{ }^{\circ} \mathrm{C}$ and $31 \mathrm{MPa}$," Procedia Earth and Planetary Science, vol. 7, pp. 762-765, 2013.

[30] H. Saishu, A. Okamoto, and N. Tsuchiya, "The significance of silica precipitation on the formation of the permeable-impermeable boundary within Earth's crust," Terra Nova, vol. 26, no. 4, pp. 253-259, 2014.

[31] M. Heřmanská, A. Stefánsson, and S. Scott, "Supercritical fluids around magmatic intrusions: IDDP-1 at Krafla, Iceland," Geothermics, vol. 78, pp. 101-110, 2019.

[32] S. W. Scott and T. Driesner, "Permeability changes resulting from quartz precipitation and dissolution around upper crustal intrusions," Geofluids, vol. 2018, Article ID 6957306, 19 pages, 2018.

[33] S. Arnórsson, J. Ö. Bjarnason, N. Giroud, I. Gunnarsson, and A. Stefánsson, "Sampling and analysis of geothermal fluids," Geofluids, vol. 6, no. 3, pp. 203-216, 2006.

[34] A. Stefánsson, I. Gunnarsson, and N. Giroud, "New methods for the direct determination of dissolved inorganic, organic and total carbon in natural waters by Reagent-Free ${ }^{\mathrm{TM}}$ Ion Chromatography and inductively coupled plasma atomic emission spectrometry," Analytica Chimica Acta, vol. 582, no. 1, pp. 69-74, 2007.

[35] W. F. Giggenbach, "Geothermal mineral equilibria," Geochimica et Cosmochimica Acta, vol. 45, no. 3, pp. 393-410, 1981.

[36] W. F. Giggenbach, "Geothermal solute equilibria. Derivation of Na-K-Mg-Ca geoindicators," Geochimica et Cosmochimica Acta, vol. 52, no. 12, pp. 2749-2765, 1988.

[37] Z.-H. Pang and M. Reed, "Theoretical chemical thermometry on geothermal waters: problems and methods," Geochimica et Cosmochimica Acta, vol. 62, no. 6, pp. 1083-1091, 1998.

[38] A. Stefánsson and S. Arnórsson, "Feldspar saturation state in natural waters," Geochimica et Cosmochimica Acta, vol. 64, no. 15 , pp. 2567-2584, 2000. 
[39] S. Arnórsson, E. Gunnlaugsson, and H. Svavarsson, "The chemistry of geothermal waters in Iceland. II. Mineral equilibria and independent variables controlling water compositions," Geochimica et Cosmochimica Acta, vol. 47, no. 3, pp. 547-566, 1983.

[40] Á. Sveinbjörnsdóttir, "Composition of geothermal minerals from saline and dilute fluids - Krafla and Reykjanes, Iceland," Lithos, vol. 27, no. 4, pp. 301-315, 1991.

[41] B. T. Gudmundsson and S. Arnórsson, "Secondary mineral-fluid equilibria in the Krafla and Námafjall geothermal systems, Iceland," Applied Geochemistry, vol. 20, no. 9, pp. 1607-1625, 2005.

[42] D. Kadko, K. Gronvold, and D. Butterfield, "Application of radium isotopes to determine crustal residence times of hydrothermal fluids from two sites on the Reykjanes peninsula, Iceland," Geochimica et Cosmochimica Acta, vol. 71, no. 24, pp. 6019-6029, 2007.

[43] A. Stefánsson, Á. E. Sveinbjörnsdóttir, J. Heinemeier, S. Arnórsson, R. Kjartansdóttir, and H. Kristmannsdóttir, "Mantle $\mathrm{CO}_{2}$ degassing through the Icelandic crust: evidence from carbon isotopes in groundwater," Geochimica et Cosmochimica Acta, vol. 191, pp. 300-319, 2016.

[44] R. O. Fournier and R. W. Potter II, “An equation correlating the solubility of quartz in water from $25^{\circ}$ to $900^{\circ} \mathrm{C}$ at pressures up to 10,000 bars," Geochimica et Cosmochimica Acta, vol. 46, no. 10, pp. 1969-1973, 1982.

[45] I. Leusbrock, S. J. Metz, G. Rexwinkel, and G. F. Versteeg, “The solubility of magnesium chloride and calcium chloride in near-critical and supercritical water," The Journal of Supercritical Fluids, vol. 53, no. 1-3, pp. 17-24, 2010.

[46] I. Leusbrock, S. J. Metz, G. Rexwinkel, and G. F. Versteeg, "Solubility of 1:1 alkali nitrates and chlorides in near-critical and supercritical water," Journal of Chemical \& Engineering Data, vol. 54, no. 12, pp. 3215-3223, 2009.

[47] A. Stefánsson and S. Arnórsson, "Gas pressures and redox reactions in geothermal fluids in Iceland," Chemical Geology, vol. 190, no. 1-4, pp. 251-271, 2002.

[48] A. Stefánsson, D. R. Hilton, Á. E. Sveinbjörnsdóttir et al., "Isotope systematics of Icelandic thermal fluids," Journal of Volcanology and Geothermal Research, vol. 337, pp. 146-164, 2017.

[49] H. Ármannsson, J. Benjamínsson, and A. W. A. Jeffrey, "Gas changes in the Krafla geothermal system, Iceland," Chemical Geology, vol. 76, no. 3-4, pp. 175-196, 1989.

[50] A. Stefánsson and J. D. Barnes, "Chlorine isotope geochemistry of Icelandic thermal fluids: implications for geothermal system behavior at divergent plate boundaries," Earth and Planetary Science Letters, vol. 449, pp. 69-78, 2016.

[51] A. Lamur, J. E. Kendrick, G. H. Eggertsson, R. J. Wall, J. D. Ashworth, and Y. Lavallée, "The permeability of fractured rocks in pressurised volcanic and geothermal systems," Scientific Reports, vol. 7, no. 1, article 6173, 2017.

[52] N. Watanabe, T. Numakura, K. Sakaguchi et al., "Potentially exploitable supercritical geothermal resources in the ductile crust," Nature Geoscience, vol. 10, no. 2, pp. 140-144, 2017.

[53] D. Norton and R. Knapp, "Transport phenomena in hydrothermal systems: the nature of porosity," American Journal of Science, vol. 277, no. 8, pp. 913-936, 1977.

[54] D. Norton and J. E. Knight, "Transport phenomena in hydrothermal systems; cooling plutons," American Journal of Science, vol. 277, no. 8, pp. 937-981, 1977.
[55] R. O. Fournier, "The behavior of silica in hydrothermal solutions," in Geology and Geochemistry of Epithermal Systems, Society of Economic Geologists, 1985.

[56] J. T. Wells and M. S. Ghiorso, "Coupled fluid flow and reaction in mid-ocean ridge hydrothermal systems: the behavior of silica," Geochimica et Cosmochimica Acta, vol. 55, no. 9, pp. 2467-2481, 1991.

[57] R. P. Lowell, P. Van Cappellen, and L. N. Germanovich, "Silica Precipitation in Fractures and the Evolution of Permeability in Hydrothermal Upflow Zones," Science, vol. 260, no. 5105, pp. 192-194, 1993.

[58] S. P. White and E. K. Mroczek, "Permeability Changes During the Evolution of a Geothermal Field Due to the Dissolution and Precipitation of Quartz," Transport in Porous Media, vol. 33, no. 1, pp. 81-101, 1998.

[59] M. Heřmanská and A. Stefánsson, "Supercritical fluids in geothermal systems - an experimental study," Goldschmidt Abstracts, vol. 1004, 2018.

[60] S. Arnórsson, A. Stefánsson, and J. Ö. Bjarnason, "Fluid-fluid interactions in geothermal systems," Reviews in Mineralogy and Geochemistry, vol. 65, no. 1, pp. 259-312, 2007.

[61] D. Parkhurst and T. Appelo, "Description of input and examples for PHREEQC version 3-a computer program for speciation, batch-reaction, one-dimensional transport, and inverse geochemical calculations," US Geological Survey, 2013.

[62] E. H. Oelkers and S. R. Gislason, "The mechanism, rates and consequences of basaltic glass dissolution: I. An experimental study of the dissolution rates of basaltic glass as a function of aqueous $\mathrm{Al}, \mathrm{Si}$ and oxalic acid concentration at $25^{\circ} \mathrm{C}$ and $\mathrm{pH}=3$ and 11," Geochimica et Cosmochimica Acta, vol. 65, no. 21, pp. 3671-3681, 2001.

[63] L. Ntihabose, Well test analysis and temperature and pressure monitoring of Krafla and Nesjavellir high-temperature geothermal fields, Iceland, UNU-Geothermal Training Programme, 2014.

[64] H. Kaasalainen and A. Stefánsson, "The chemistry of trace elements in surface geothermal waters and steam, Iceland," Chemical Geology, vol. 330-331, pp. 60-85, 2012. 

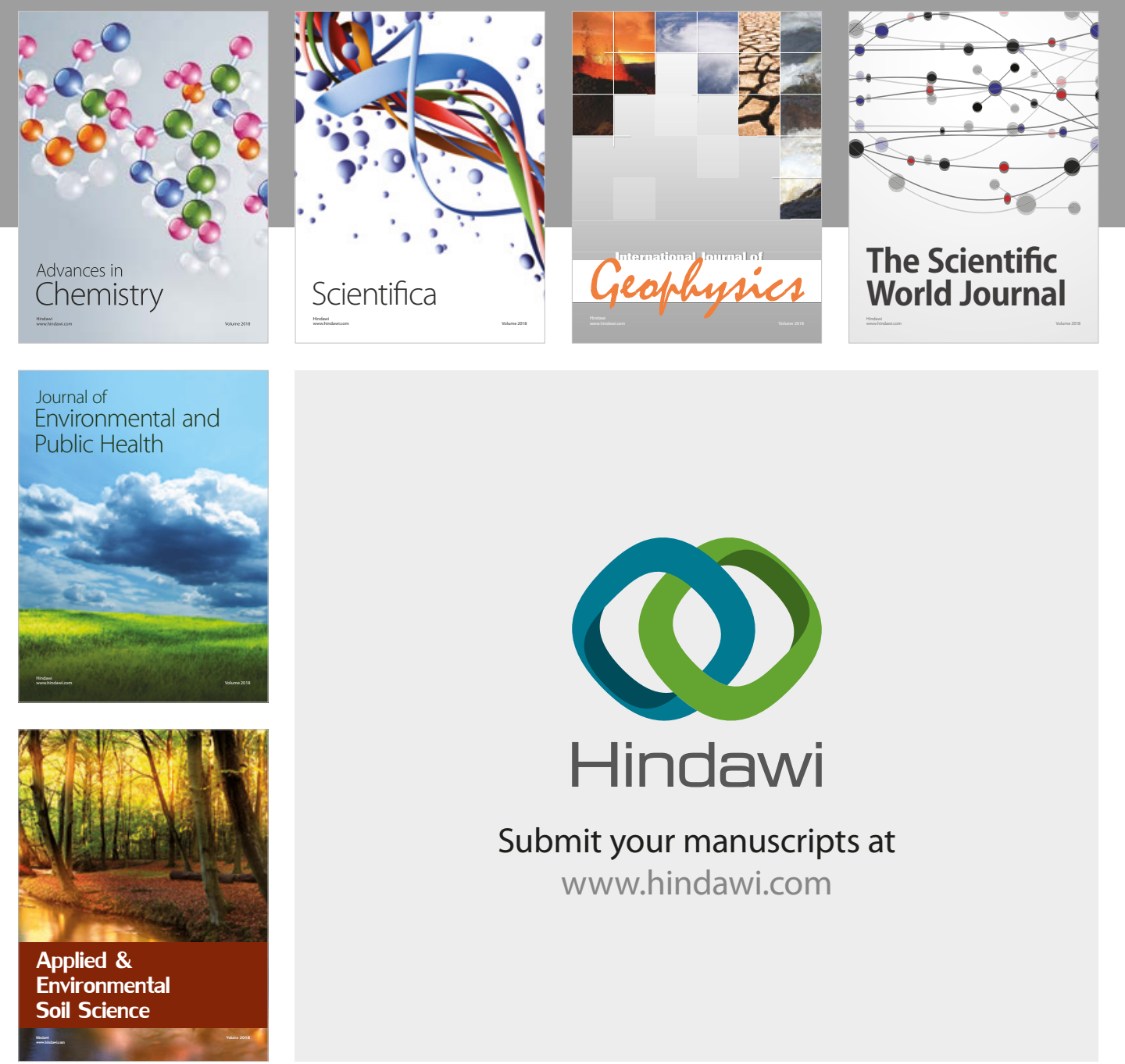

The Scientific

\section{World Journal}
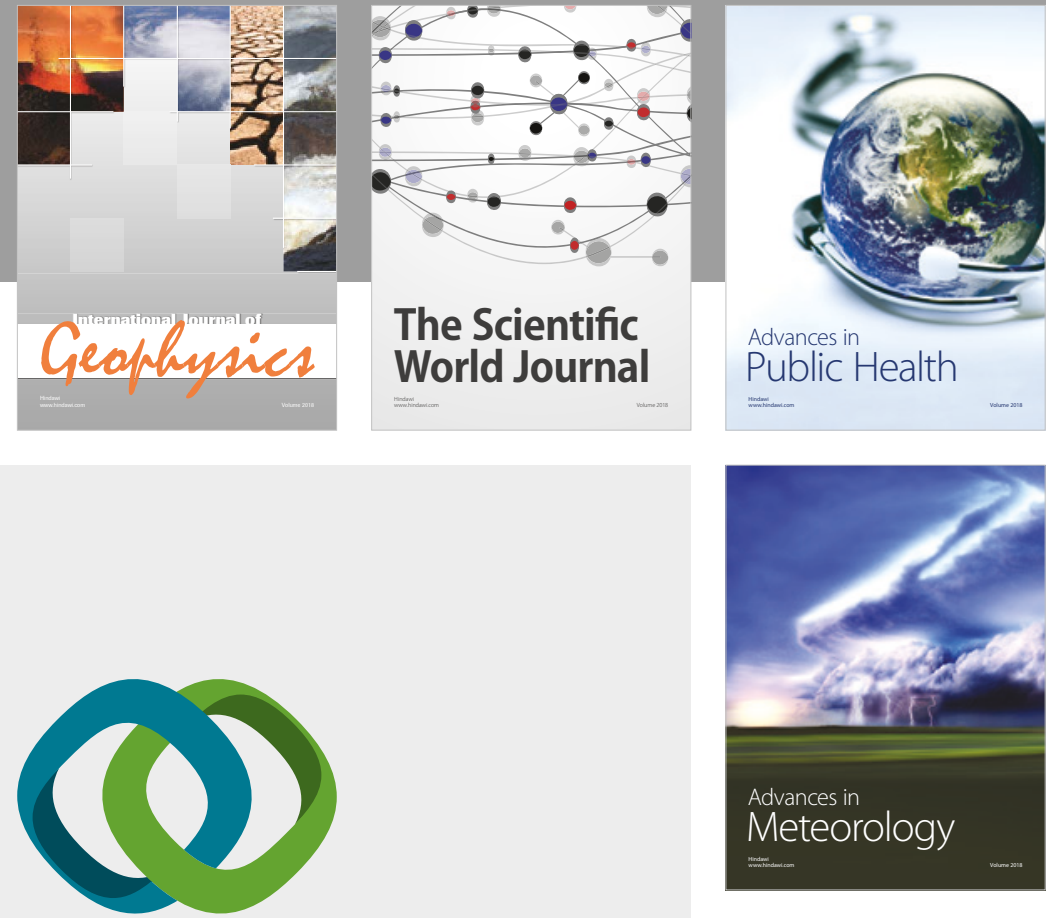

Advan

Public Health

\section{Hindawi}

Submit your manuscripts at

www.hindawi.com
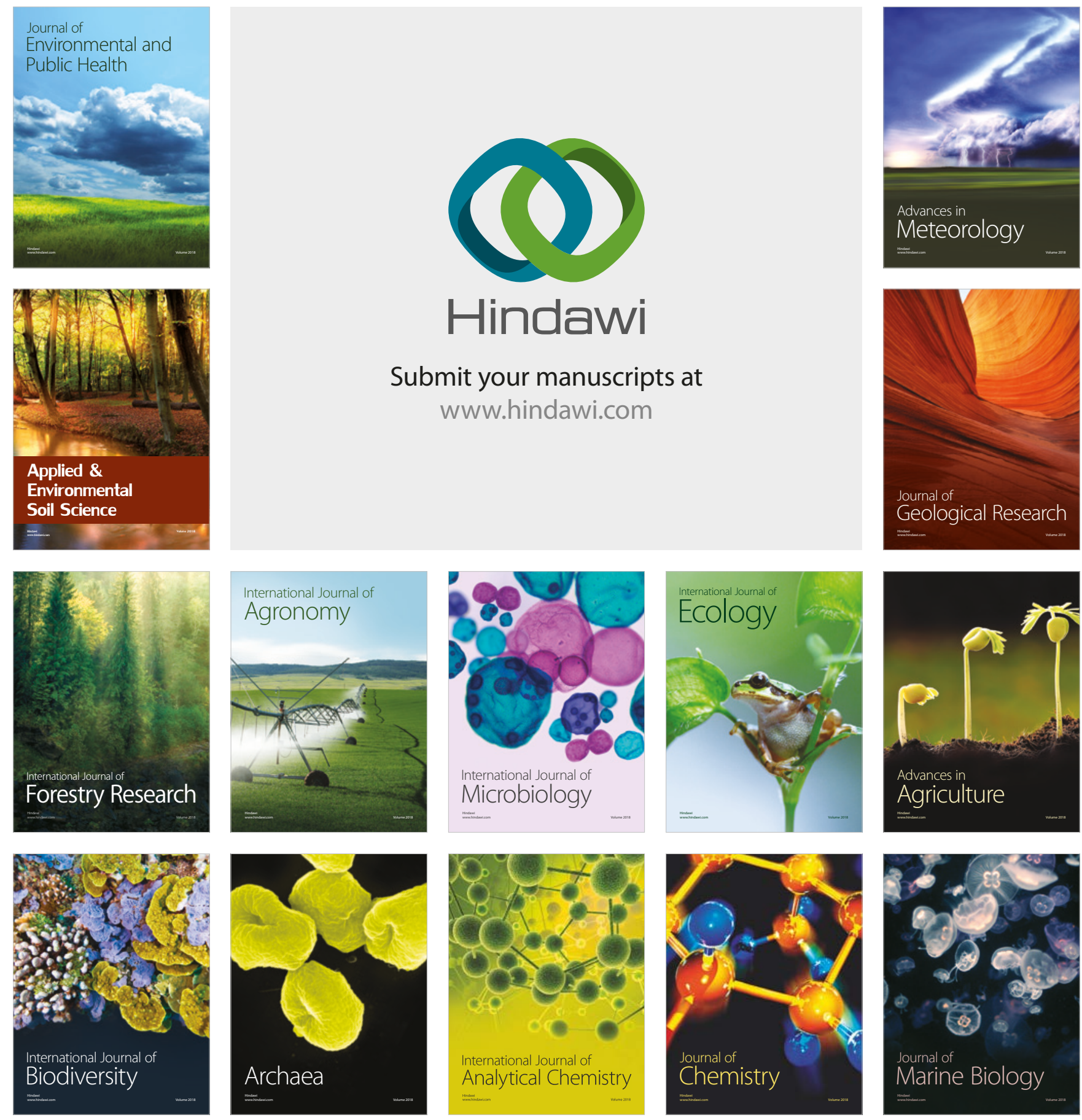